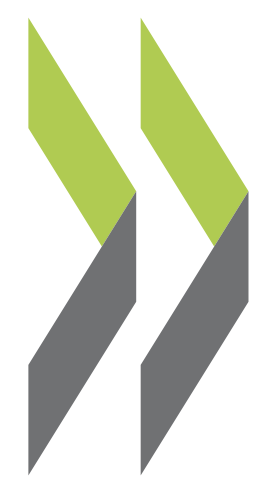

OECD Local Economic and Employment Development (LEED) Papers 2020/04

\section{Local ability to rewire and socioeconomic} performance: Evidence from US counties before and after the Great Recession

\section{Mark Partridge,}

\section{Alexandra Tsvetkova}


OECD Local Economic and Employment Development (LEED) Papers

\title{
Local ability to "rewire" and socioeconomic performance
}

\section{Evidence from US counties before and after the Great Recession}

By Mark Partridge and Alexandra Tsvetkova

\begin{abstract}
The paper examines the effects of three groups of factors (county economic structure, social/demographic attributes and geography) on employment growth and poverty change in US counties before and after the Great Recession. It finds that the industrial structure that facilitates inter-industry employee flows ("rewiring") is of increasing importance post-Recession. In particular, this measure is associated with employment growth in underperforming counties suggesting that removing barriers to the flow of resources within lagging economies and increasing their adaptability potential might be a viable policy option.
\end{abstract}

JEL codes: J62; O18; R11

Keywords: employment growth, inter-industry employee flows, local economic rewiring, poverty change, Great Recession, US 


\section{ABOUT THE OECD}

The OECD is a unique forum where governments work together to address the economic, social and environmental challenges of globalisation. The OECD is also at the forefront of efforts to understand and to help governments respond to new developments and concerns, such as corporate governance, the information economy and the challenges of an ageing population. The Organisation provides a setting where governments can compare policy experiences, seek answers to common problems, identify good practice and work to co-ordinate domestic and international policies.

\section{ABOUT OECD LOCAL ECONOMIC AND EMPLOYMENT DEVELOPMENT (LEED) PAPERS}

The OECD Local Economic and Employment Development (LEED) Programme Papers present innovative ideas and practical examples on how to boost local development and job creation. A wide range of topics are addressed, such as employment and skills; entrepreneurship; the social economy and social innovation; culture; and local capacity building, among others. The series highlights in particular policies to support disadvantaged places and people, such as the low skilled, the unemployed, migrants, youth and seniors.

OECD Working Papers should not be reported as representing the official views of the OECD or of its member countries. The opinions expressed and arguments employed are those of the author(s).

Working Papers describe preliminary results or research in progress by the author(s) and are published to stimulate discussion on a broad range of issues on which the OECD works. Comments on Working Papers are welcome, and may be sent to the Centre for Entrepreneurship, SMEs, Regions and Cities, OECD, 2 rue André-Pascal, 75775 Paris Cedex 16, France.

This paper is authorised for publication by Lamia Kamal-Chaoui, Director, Centre for Entrepreneurship, SMEs, Regions and Cities, OECD.

This document, as well as any statistical data and map included herein, are without prejudice to the status of or sovereignty over any territory, to the delimitation of international frontiers and boundaries and to the name of any territory, city or area.

\section{(c) OECD 2020}

You can copy, download or print OECD content for your own use, and you can include excerpts from OECD publications, databases and multimedia products in your own documents, presentations, blogs, websites and teaching materials, provided that suitable acknowledgment of the source and copyright owner is given. All requests for public or commercial use and translation rights should be submitted to rights@oecd.org. 


\section{Acknowledgements}

The authors thank Karen Maguire (OECD Local Employment, Skills and Social Innovation (LESI) Division) and Rudiger Ahrend (OECD Economic Analysis, Statistics and Multilevel Governance Section) for detailed comments and Elisa Campestrin (OECD Trento Centre for Local Development) for help with formatting the document. The paper was presented at the 2018 ASSA Annual Meeting in Philadelphia, PA; Research Workshop on Expanding Opportunities through Economic Development and Workforce Development Initiatives co-hosted by the Federal Reserve Bank of Atlanta and the W.E. Upjohn Institute for Employment Research; the 58th ERSA Congress in Cork, Ireland, and as a part of the Willian G. Murray Memorial Lecture series at lowa State University, USA. The authors are indebted to the participants for comments. Mark Partridge acknowledges with gratitude partial support of the USDA AFRI grant \#11400612 "Maximizing the Gains of Old and New Energy Development for America's Rural Communities". 
4

\section{Table of contents}

Acknowledgements 3

Executive summary $\quad 5$

1 Introduction $\quad 7$

2 Is basic economic well-being diverging? $\quad 9$

3 Literature review 11

4 Empirical implementation, data and variables 13

5 Estimation results and discussion $\quad 21$

Conclusions and policy implications $\quad 29$

Tables

Table 4.1. Full list of variables and sources 19

Table 5.1. OLS estimation results for annualised employment growth 23

Table 5.2. Quantile regression results for annualised employment growth, 2010-2015 minus 2000-2007 24

Table 5.3. OLS estimation results for average change in poverty 26

Table 5.4. Quantile regression results for average poverty change, 2010-2015 minus 2000-2007 27

Figures

Figure 2.1. Average standard deviation in per-capita income in the US 9

Figure 5.1. Pre- and post-recession employment growth dynamics 21

Figure 5.2. Pre- and post-recession poverty dynamics 25 


\section{Executive summary}

Spatial inequalities in well-being have been increasing in the US in the last decades. After the Great Recession, the inequalities continued to grow, as many counties performed worse compared to the prerecession period in terms of employment growth and poverty reduction.

Weaker economic performance post-recession compared to own performance before the crisis can indicate that the traditional engines of growth were not working as before. Indeed, our analysis documents changes in the role played by various factors in shaping employment growth and poverty reduction after the Great Recession in the US counties. Although the changes are relatively modest, they consistently point to an increasing role played by economic factors and an unchanged or decreasing role of human capital and natural amenities.

Two sets of economic characteristics are included in the analysis. Traditional static measures of industrial composition (e.g. share of manufacturing or the degree of diversity) are supplemented with dynamic measures that (1) quantify the local growth prospects based on the national growth trends (industry mix term) and (2) approximate the degree of "rewiring" in the local economy.

Three variables are used to capture the "rewiring" ability. The first measure quantifies changes in the industrial composition of a county (employee reallocation across industries within a local economy). The second measure quantifies changes in the occupational composition (employee reallocation across occupations). The third variable approximates the propensity of the local industrial structure to accommodate higher inter-sectoral job flows.

Controlling for a host of other factors, the dynamic measures of the local "rewiring" ability consistently emerge as predictors of better performance in terms of employment growth particularly in rural areas and counties that underperformed post-recession compared to the prerecession period.

In particular, the analysis leads to the following conclusions.

- Growth mechanisms differ across counties depending on their economic performance, i.e. factors associated with greater employment growth are different for growing and stagnating (or declining) counties. The same is true for change in poverty, i.e. factors linked to poverty reduction in lowpoverty counties are different from those in high-poverty areas.

- Industrial structure that consists of industries growing nationally (a positive demand shock) helps to boost employment growth and to cut poverty rates only in more well-off places (those in the middle and at the higher end of economic performance distribution).

- Less well-off counties appear to be unable to benefit from the national growth processes, falling further behind.

- For places with reduced ability to benefit from the national growth trends, economic "rewiring" appears to contribute to improved performance as measured by employment growth. 
- Both rural and lagging places performed significantly better in terms of employment growth postRecession if their industrial composition was conducive to greater inter-sectoral worker flows (e.g., workers from one sector were able to move into another) and if they enjoyed larger changes in occupational structure, with relatively more people moving from one occupation to another.

These findings suggest that growth of local economies increasingly depends on their ability to adjust to the changing realities of interconnected and technology-dependent world. Local "rewiring" is one adjustment mechanism that appears to work particularly well for rural and weaker-performing counties in the US. Lagging areas should encourage labour flows within the region, ideally from lower- to better-performing sectors, industries, firms and occupations.

While the specific ways to encourage labour flows should be selected based on local conditions, a set of possible instruments includes retraining of the labour force (e.g. through vocational or on-the-job training and other programmes), reducing regulatory barriers (e.g. easing occupational licensing requirements in some cases) and encouraging the uptake of digital and other types of innovation that can allow more productive use of human capital or lead to growth-enhancing creative destruction. 


\section{Introduction}

The United States has always experienced spatial differences in economic activity and well-being (Carlino and Mills, 1996[1]; Rey and Montouri, 2010[2]), although long-running convergence historically mitigated the disparities (Carlino and Mills, 1993[3]; Caselli and Coleman, 2001 [4]). Recent structural changes related to deindustrialization, technological change, and globalization have weakened or even reversed the convergence forces. This change has reinforced income differentials, particularly in the Rustbelt, coal country, and much of rural America, which found themselves unprepared to face the new challenges (Autor, Dorn and Hanson, 2013[5]; Autor, Katz and Kearney, 2008 $\left.{ }_{[6]}\right)$. The uneven recovery from the Great Recession has further fuelled the perceptions that many places are being left behind (Lowrey, 2017[7]). ${ }^{1}$

Against this backdrop, we first document the trends of converging and then diverging economic fortunes across US states and counties since the 1960s. We show that the common perception of regional differences in economic performance between the pre- and post-recession periods is correct. In order to understand reasons for these trends and to help inform labour market policies aimed at improving local economic resilience, we perform a set of econometric analyses using more recent data. For the 2000-2015 period, we econometrically explore the underlying drivers of economic performance at the county level. We bring together a wide range of factors that have been shown to shape regional socioeconomic performance including economic structure, social/demographic attributes, and geography i.e. natural amenities and a position within the urban-rural hierarchy. ${ }^{2}$ The selection of the three general variable groupings follows the economic development literature (Partridge, 2010[8]; Rupasingha, Goetz and Freshwater, 2005[9]; Beyers, 2013 [10] $)$. Understanding the underlying forces - and possible changes in their influence between the pre- and post-Great Recession period ${ }^{3}$ - would help shape up-to-date policy responses aimed at bringing localities left behind after the Great Recession back to the table of opportunity. Indeed, this roadmap is consistent with recent calls to depart from development strategies that are ineffective and to identify new approaches (Fodor, 2012[11]).

A novel contribution of our paper is that we complement traditional, mainly "static" measures of economic structure with measures that approximate the ability of a county to rewire by reallocating employees across sectors. Researchers have long highlighted the importance of sectoral shifts and restructuring for the local socioeconomic performance (Fan and Casetti, $1994_{[12]}$ ). The three measures of county labour market

\footnotetext{
${ }^{1}$ Center for American Progress (2018[67]) provides a comprehensive summary of these trends. The side effects of some of the trends, such as a wrenching opioid crisis and related "deaths of despair" (Case and Deaton, 2015[68]) have been extensively documented (Meara and Skinner, 2015[69]) and studied (Betz and Jones, 2018[70]).

${ }^{2} \mathrm{~A}$ few studies bring together a wide range of explanatory variables when analasing county-level performance in the US (Rupasingha, Goetz and Freshwater, 2005[9]). In some cases, researchers prefer to reduce the number of variables used in estimation via principal component analysis, which is useful in predicting outcomes but deprives a researcher the ability to measure the relative impact for each individual variable retained as a part of the principal components (Khatiwada, 2014[71]).

${ }^{3}$ Previous research documents changing patterns of effects at least for some determinants of regional economic performance. For example, Foster, Grim and Haltiwanger $\left(2016_{[72]}\right)$ find that the pace of reallocation in the labour market fell during the Great Recession. Likewise, Moscarini and Postel-Vinay (2016[73] $)$ conclude that the Great Recession has reduced the movement from smaller to larger employers.
} 
adjustments in our study offer insights into the role played by industrial structure conducive to employment reallocation as well as by industrial and occupational shifts within local economies.

There is emerging evidence that the Great Recession has changed many economic relationships (Elsby, Hobijn and Sahin, 2010[13]; Elsby, Hobijn and Şahin, 2013 $\left.{ }_{[14]}\right)$. In assessing such changes, we examine the pre-recession (2000-2007), recession (2007-2010) and post-recession (2010-2015) periods. We use several econometric techniques, such as cross-sectional, first-difference, and quantile regression to understand contemporary determinants of local economic well-being. Our main analysis compares postRecession to pre-Recession period in a difference-in-difference type framework (Bertrand, Duflo and Mullainathan, 2004[15]) and investigates the changing importance of each factor in explaining employment growth and change in poverty rates for US counties.

We find that the role played by industrial composition (if it consists of fast- or slow-growing - at the national level - industries) is of increasing importance. Another increasingly important factor is the local labour market's ability to "rewire" by facilitating the movement of workers across industries and occupations in response to changing economic conditions. Interestingly, after the dynamism of a local economy is accounted for, industrial diversity is insignificant, suggesting that diversity's role in stabilizing and promoting growth in local communities (Hammond and Thompson, 2004 ${ }_{[16]}$; Watson and Deller, 2017 ${ }_{[17]}$ ) may be working more through employee reallocations. Some of our most policy-relevant findings come from the quantile analysis of job growth. For counties in the lower part of the response function distribution, the labour-market "rewiring" ability emerges as predictor of growth, suggesting that enhancing labour flows within lagging economies might be a viable policy option.

In what follows we start with a brief descriptive analysis to ascertain that economic well-being is diverging geographically. Concluding that there are good reasons to believe so, we follow with a short literature review. We next describe the data and empirical specifications followed by the empirical results. We separately discuss the results for job growth and poverty change. The paper finishes with our concluding thoughts and policy suggestions. 


\section{Is basic economic well-being diverging?}

The uneven recovery from the Great Recession contributed to the growing sense that some places are being left behind. Yet, this flies against conventional economic wisdom from neoclassical growth theory that regional incomes have been converging since the Civil War (Barro and Sala-I-Martin, 1990 [18]). . To investigate, using US Bureau of Economic Analysis (BEA) data, we calculate the average standard deviation in per-capita income for each year during the 1969-2016 period (standardized by national percapita income) for US states and counties. Specifically, we calculate unweighted standard deviations that reflect differences across space and standard deviations weighted by population to show spatial differences for the average person (which is national income inequality minus the within-state/county component of inequality). The results are plotted in Figure 2.1 where the left panel shows unweighted standard deviations for states and counties, and the right panel shows corresponding standard deviations weighted by population.

Figure 2.1. Average standard deviation in per-capita income in the US

Unweighted (left panel) vs. weighted by population (right panel).
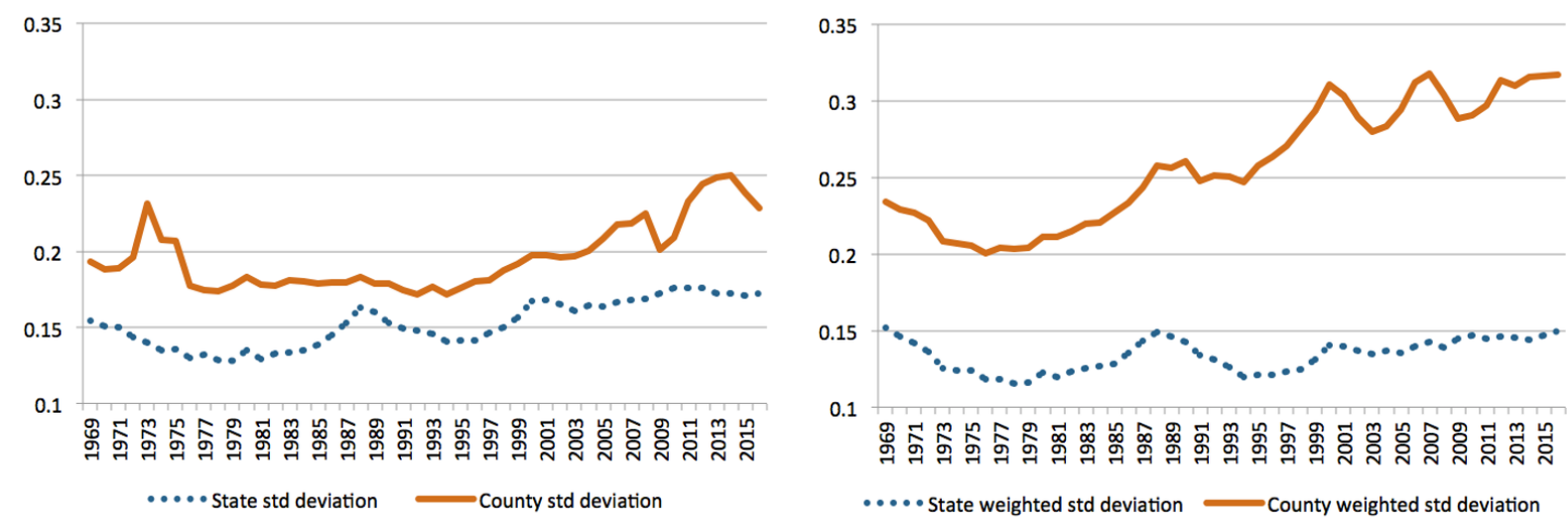

Source: The authors' calculations based on the US Bureau of Economic Analysis data.

Figure 2.1 shows that the state-level focus masks considerable within-state inequality. Turning to the county-level results, the unweighted standard deviations show a slight downward trend until 1994, falling to about 0.17 before rising almost $50 \%$ to 0.25 in 2014 , then falling slightly to 0.23 in 2016 . The populationweighted standard deviations illustrate a stronger upward trend. After falling slightly to about 0.20 in 1976 , the weighted standard deviation steadily increases to about 0.32 in 2016 , or a rise of about $60 \%$. The analysis was repeated by removing transfer payments and the divergence pattern for the resulting "market" per-capita personal income is even more striking, further suggesting that economic opportunities are 
increasingly geographically unequal (not shown) ${ }^{4}$. So while these trends emerged pre-recession, they have since continued.

We also did the same using the unweighted and weighted standard deviations of annual wage and salary job growth. There is steady convergence of job growth rates until 2010. After which, there has been about a one-third increase in the unweighted variation between 2010-2016, though the weighted standard deviation had a more modest increase (not shown). The divergence in job growth is much more modest, though the post-recession period represents a departure from the pre-recession trend of convergence. The implication is that some regions are increasingly lagging and that the trends of divergence now extend to job growth as well as income. ${ }^{5}$

There are also reasons to point to a relative decline in rural America compared to urban America, which has been widely covered by the popular press (Adamy and Overberg, 2017 ${ }_{[19]}$ ). For example, in the immediate pre-recession period, nonmetropolitan America was making rapid progress in narrowing the relative population growth gap with metropolitan America (US Department of Agriculture Economic Research Service, 2020[20]). Yet, after the Great Recession, nonmetropolitan population growth virtually tanked, even turning negative for much of the post-recession period (which is unprecedented since the Great Depression). While our focus is not to assess why there is differential growth, it does support the public perception that the fortunes of rural areas have turned for the worst in recent years.

\footnotetext{
${ }^{4}$ We also tested for the presence of spatial autocorrelation of per-capita personal income during the 1989-2015 period as evidenced by the Moran's I statistic (in earlier years, the US Bureau of Economic Analysis does not report income data for some counties, which create "holes" in the contiguity matrix preventing us from obtaining Moran's I for years leading to 1989). In every year, the Moran's I is statistically significant at the 0.001 level, strongly suggesting that per capita income is spatially clustered. The magnitude of the statistic has a general negative trend that bottoms at 0.157 in 2006, then grows to 0.254 in 2011 and decreases slightly afterwards with the value of 0.207 in 2015 .

${ }^{5}$ The unweighted standard deviation in market per-capita income at the county level bottomed out in 1978 at 0.20 , then rose to 0.32 in 2014 before settling to 0.29 in 2016 . The corresponding data for the weighted values are bottoming out at 0.23 in 1978 and rising to just over 0.39 in 2016.
} 


\section{Literature review}

The literature investigating the determinants of regional economic growth is enormous and highlights many factors that are important for local socioeconomic well-being across space and time. Such factors can be generally grouped into several broad categories ${ }^{6}$ : (1) industry diversity (Watson and Deller, 2017 [17]), (2) human capital and innovation (Faggian and Mccann, 2009 [21]; Fallah, Partridge and Rickman, 2014[22]; Goetz and Hu, 1996[23]), (3) population demographics and labour force participation ( (Stephens and Deskins, 2018[24]; Amcoff and Westholm, 2007[25]), (4) culture, social capital and related factors ( (Camagni, 2009[26]; Rupasingha, Goetz and Freshwater, 2000[27]; Rupasingha, Goetz and Freshwater, 2006 [28]; Akçomak and ter Weel, 2009[29]), and (5) amenities (Deller et al., 2001 ${ }_{[30]}$; Deller, Lledo and Marcouiller, $\left.2008_{[31]}\right)$ among others. The performance of rural and remote regions has been further defined by remoteness and access to agglomeration (Brezzi, Dijkstra and Ruiz, 2011 [32]; Andersson and Lööf, 2011 [33]; Partridge et al., 2007[34]; Partridge et al., 2009[35]).

The Great Recession threw the US economy from its long-term growth trend and further intensified scholarly debates on the determinants of regional economic growth. The central topic has increasingly moved to the notion of resilience-i.e., the ability of regions to withstand and recover from shocks. Aside from a concerted effort to operationalize and measure resilience, the discussion focuses on the same broad categories described above (Martin, Sunley and Tyler, 2015[36]). The economic resilience literature suggests that the Great Recession revealed many underlying discrepancies in regional economic fundamentals, speeding up the process of divergence in economic fortunes that could be undetectable during prosperous times (Lagravinese, $\left.2015_{[37]}\right)$. Some researchers argue the Great Recession especially hurt regions that lacked strong engines of growth (Martin, Sunley and Tyler, $2015_{[36]}$ ) and exacerbated the long-simmering socioeconomic problems in rural and lagging communities. Others claim that the Great Recession was a watershed for the US economy (Florida, 2009 [38]; Gore, 2010[39]), implying that the nation will need new ways of responding to the rapidly changing economic reality.

When one thinks about economic resilience as an adjustment process to a shock, the economic variables currently used in the literature may be insufficient, as they focus on the structure of a local economy (Lagravinese, 2015[37]) and generally ignore the dynamics of actually how a local economy readjusts and rewires. Thus, a key goal of our study is to propose new dynamic measures of local economic adjustment and to assess their effects on economic outcomes.

The literature also points to an important role played by various social/demographic factors in defining regional performance. For instance, the importance of human capital for economic growth is well established (Nelson and Phelps, 1966[40]; Lucas, 1989 ${ }_{[41]}$ ). Other research points to local racial and ethnic composition as important for socioeconomic well-being. For example, Easterly $\left(2001_{[42]}\right)$ and Partridge and Rickman (Partridge and Rickman, 2005[43]) document that high-poverty places tend have greater minority populations.

Putnam, Leonardi and Nanetti $\left(1993_{[44]}\right)$ stress the role of social capital in regional socioeconomic outcomes. The level of social capital in a community is generally related to participation in associational activities and trust. Several empirical studies find a positive effect of social capital on a range of US

${ }^{6}$ Of course, there are many ways to group economic performance determinants into broad categories (Martin et al., $2016[75])$. 
economic growth indicators (Rupasingha, Goetz and Freshwater, 2000[27]; Rupasingha, Goetz and Freshwater, 2006[28]).

Amenity-led economic development has received significant scholarly attention as well (Green, Deller and Marcouiller, 2005[45]). Many high-amenity places have been able to capitalize and attract in-migration, even to rural areas (Partridge, 2010 ${ }_{[8]}$ ), although it is unclear how the Great Recession and housing bust affected the long-run prospects of high-amenity locales. 


\section{Empirical implementation, data and variables}

We start our analysis with a descriptive look at changes in poverty and job growth pre- and post-recession followed by cross-sectional regressions for the post-recession period (2010-2015). Our basic theoretical approach follows the standard spatial equilibrium model in which profits and household utility are equalized across space (Glaeser and Gottlieb, 2009 ${ }_{[46]}$; Glaeser and Gottlieb, 2008 $8_{[47]}$ ). While disequilibrium shocks (e.g., technological change, demand shocks, macroeconomic fluctuations) are always hitting the system, the model is best used to show the regional economy's adjustment toward equilibrium. This represents our initial econometric analysis of the factors driving county-level job growth and poverty rates. Although we try to mitigate any endogeneity, cross-sectional approaches can suffer from omitted variable bias.

In the next step, we repeat the analysis using a differencing strategy in order to account for time-invariant unobservable factors and to benchmark the post-recession dynamics against the pre-recession period (we subtract the 2000-2007 values from the 2010-2015 values for dependent and main explanatory variables). We then estimate the models with differenced dependent and main explanatory variables to isolate changes that occurred since the recession (the obtained coefficients should capture the importance of the corresponding factors post-recession relative to their importance pre-recession).

Finally, to assess heterogeneity among fast- and slow-growing locales, quantile regression of the differenced models is used to estimate changes at the $10^{\text {th }}, 50^{\text {th }}$ and $90^{\text {th }}$ percentiles of the conditional distribution of the dependent variable. The analyses are performed using data for over 3,000 counties in the continental US. To follow the long tradition in the literature, all models are estimated separately for nonmetro (1986 total) and metro (1 052 total) counties to avoid aggregation bias and to account for differing levels of agglomeration. The separate analyses are also justified because the divergence of local economic fortunes and the differing industry compositions are expected to affect rural and urban America differently.

\section{Cross-section "level" equations for 2010-2015}

The cross-sectional model for the 2010-2015 period is shown in Equation (1):

$Y_{c \tau}=\beta_{0}+\boldsymbol{\beta}_{1} \operatorname{ECON1} 1_{c \tau}+\boldsymbol{\beta}_{2} \operatorname{ECON2}_{c t}+\boldsymbol{\beta}_{3} \operatorname{SOC}_{c t}+\boldsymbol{\beta}_{4} G E O G_{c}+X \boldsymbol{\beta}+\theta_{s}+\varepsilon_{c \tau}$

where $c$ denotes county, $\tau$ is a time period from time $t$ to time $t 1$ (here from 2010 to 2015), and subscript $s$ indicates state. The error terms $\varepsilon_{c \tau}$ are clustered within one of $179 \mathrm{BEA}$ economic areas to account for spatial autocorrelation. ${ }^{7}$ The clustering within BEA economic areas captures the high integration within the areas and the clustering allows each region to have its own form of spatial autocorrelation. ${ }^{8}$ Our discussion focuses on the 2010-2015 results.

\footnotetext{
${ }^{7}$ We also estimate spatial Durbin models, which produce generally identical results.

${ }^{8}$ We could account for spatial autocorrelation with a traditional spatial econometric approach. However, that would require us to impose a structure on the way the residuals are connected through a weight matrix $\mathbf{W}$. The matrix is
} 
The two dependent variables are the 2010-2015 annual (average) change in the poverty rate and the 20102015 annualized job growth. Since our sample periods have different durations, we use annualized and average measures to maintain comparability. The vectors ECON1, ECON2, SOC, and GEOG refer to economic indicators measured over the period under consideration, initial-period economic indicators (measured at the beginning of the period), initial-period social indicators and the county's geographical attributes, respectively. Using explanatory variables at their beginning levels should alleviate reverse causality concerns, though omitted variable bias may still exist. To be sure, our key economic variables should be exogenous as described below. The vector $\boldsymbol{X}$ comprises a set of controls and $\theta_{s}$ are state dummies to capture the role of state-specific policies on growth and other factors that are time-invariant in each state.

The average annual change in the poverty rate is calculated by dividing the change in poverty over the whole period by the number of years, whereas annualized job growth is calculated using the compound annual growth rate formula ${ }^{9}$. The poverty data are from the Small Area Income and Poverty Estimates (SAIPE) program and employment is from US Census Bureau County Business Patterns (CBP). ${ }^{10}$

One limitation of the County Business Patterns dataset is that it has numerous suppressions in cases when the US Census Bureau is concerned that individual firms can be identified in the data. Generally, smaller rural counties have more suppressed values. Thus, we use the CBP four-digit level data after a linear programming algorithm is applied to calculate and fill in the suppressed values. The source for these data is the W.E. Upjohn Institute for Employment Research that uses the Isserman and Westervelt (2006[48]) algorithm in constructing the "unsuppressed" version of the data. ${ }^{11}$

Our models include two sets of economic characteristics, more traditional measures of industrial structure and relatively novel variables that approximate the degree of "rewiring" of the local economy. Our main approach is to consider the role of industrial structure in determining job growth (after controlling for other features) and to separate its effects from the effects of the ability of labour-markets to reallocate workers. Does the ability of an economy to "rewire" or shift resources across industries and occupations (theoretically from weak- to strong-performing industries) have a tangible effect on improving local performance? The answer to this question is important to understanding the underlying mechanisms of how local economic resilience manifests itself.

The following variables constitute the combined ECON vector. The industry mix variable, IndMix, is the predicted growth rate of county employment if all its industries grow at the corresponding national growth rates. This measure is sometimes called the Bartik instrument (Bartik, 1991 [49]) and is routinely used as an exogenous instrument for employment growth. Rather, we are using it as an exogenous measure of demand shocks that arise from a unique industry composition of each local area (Tsvetkova, Partridge and Betz, 2019[50]; Betz and Partridge, 2013[51]).

usually selected in an ad hoc manner, which may not reflect the actual connectivity or may be only loosely related to the actual economic region-while clustering encompasses all forms of spatial autocorrelation that may exist though a $\mathbf{W}$ matrix.

${ }^{9}$ AnnEmpGr $_{c \tau}=\left(E m p_{c t 1} / E m p_{c t}\right)^{1 / n}-1$ and AvPovChange $e_{c \tau}=\left(\right.$ PovRate $_{c t 1}-$ PovRate $\left._{c t}\right) / n$, where $n$ is the number of years between $t$ and $t 1$.

${ }^{10}$ Note that the CBP data do not include government employment, which means that our results are most applicable to the private sector.

${ }^{11}$ See Weinstein, Partridge and Tsvetkova $\left(2018_{[74]}\right)$ for details of the CBP data used here. The values reported in CBP are highly correlated with Quarterly Census of Employment and Wages in the range of 0.95, at least for some industries, though it appears to be not quite as accurate as the data provided by the private vendor EMSI, which we use in a few cases. However, the advantage of the CBP data is that the algorithm is replicable and has undergone a peer review. 
Equation (2) shows how IndMix is calculated:

IndMix $_{c \tau}=\sum_{i=1}^{N} S h_{c i t} N a t G r_{i \tau}$

where all subscripts are identical to Equation (1) with subscript $i$ indicating industry at the 4-digit NAICS level and there are $N$ industries. $S h_{c i t}$ is the share of industry is employment in county $c$ at the beginning of the period $\tau$ and $N a t G r_{i \tau}$ is the annualized national industry growth rate over the period. Because national growth rates and initial industry shares are used, industry mix is typically assumed to be exogenous. This condition is true as long as there are no labour supply responses associated with lagged industry composition aside from labour supply variables we already control for (reducing any labour supply factors in the residual correlated with lagged industry composition).

The JobsFlow is a measure that approximates the expected ease of finding a job in a different sector but in the same location if, for example, one is displaced from work. The variable quantifies the degree to which the industrial structure of a county is composed of industries that are more likely (higher value of the variable) or less likely (smaller value of the variable) to share workers. JobsFlow is calculated using the job-to-job flow information at the 2-digit NAICS level from the US Census Bureau Longitudinal EmployerHousehold Dynamics (LEHD) program and industrial composition of a county at the beginning of a period as reflected in the "unsuppressed" version of the CBP.

The variable JobsFlow is calculated as follows.

JobsFlow $_{c \mathrm{t}}=\sum_{i} \sum_{j} S h_{c i t} S h_{c j t}$ Flow $_{i j}$

where $S h_{c i t}$ is county c's share of employment in the origin sector $i$ at time $t$, the beginning of a period under consideration; $S h_{c j t}$ is county $c^{\prime}$ 's share of employment in the destination sector $j$ at time $t$ and $F l o w_{i j}$ is the percent of total employment leaving sector $i$ that ends up in sector $j$ as reflected in the LEHD. Thus, for each industry $\times$ industry pair, the larger the size of the job flow Flow $w_{i j}$ from industry $i$ to industry $j$, the easier it should be to move between the two sectors if there are job losses or job growth in either sector. The sectors are defined at the 2-digit NAICS level and circular flows within a sector are excluded, i.e. when calculating (3), $i \neq j$. Because the job flow data are at the national level, like the industry mix term, JobsFlow variable should be exogenous. The CBP is the data source for employment shares used in calculations.

The next two measures, OccEmpMobility and IndEmpMobility, approximate the dynamics (changes) in a local economy over period $\tau$ as evidenced by moves of employees across industries and occupations during the period (Levernier, Partridge and Rickman, 2000[52]). It follows the logic of the dissimilarity index used in research on racial segregation and diversity (Ellis, Wright and Parks, 2004[53]) but instead of differences in a locality's racial composition, it captures dissimilarity in employment distribution at the beginning and the end of a period. The measures show the percentage of total county employment at the end of a period that needs to move to other industries or occupations, respectively, in order for the industrial/occupational composition of the local economy to be the same as at the beginning of a period. A greater number suggests that industrial or occupational structure changed more during the period, likely indicating higher employee flows across industries and occupations. The motivation for these two measures is similar to the JobsFlow variable except it focuses more on the localities with a track record of shifting workers instead of localities with industrial composition consisting of industries with the national track record of job-flow mobility.

Equation (4) shows the index:

EmpMobility $_{c \tau}=\sum_{i}\left|S h_{i c t 1}-S h_{i c t}\right|$

where $i$ refers to an industry at the 4-digit NAICS level and all other subscripts are defined as before. The $\mathrm{CBP}$ is the data source for the IndEmpMobility variable whereas a proprietary data set from Economic 
Modelling Specialists, Intl. (EMSI) ${ }^{12}$ on the county-level employment by occupation is used to derive the OccEmpMobility variable.

Also included in the ECON vector is an industry diversity measure, IndDiversity, which is calculated as follows using the EMSI data:

IndDiversity $_{c \mathrm{t}}=10,000-\sum_{i} S h_{\text {cit }}^{2}$

where $S h_{c i t}^{2}$ is a squared share of employment in industry $i$ (at 4-digit NAICS level) in county $c$ in year $t$, which is the beginning of the period $\tau$. Subtracting the summed squared shares from the maximum possible value ensures that the larger values of IndDiversity correspond to a more diverse industry structure. The general expectation is that industry diversity is associated with better economic outcomes because shocks to one sector are less likely to lead to adverse aggregate outcomes. In more industrially diverse economies, average share of a single industry or a sector tends to be smaller meaning that it would be easier for its former workforce to find jobs elsewhere should there be industry-specific layoffs (Hammond and Thompson, 2004[16]; Watson and Deller, 2017[17]). By controlling for diversity, we also exclude a possibility that our labour-market "rewiring" ability measures are really just picking up more general diversity effects that have already been found in the literature.

The last two variables included in the vector of economic factors are a share of manufacturing in total county employment, ManufShare and a share of labour-intensive (low-wage) manufacturing, LowWageManufShare ${ }^{13}$ calculated using the EMSI data. We use deep lags of this variables in our models to mitigate potential endogeneity concerns, i.e. the 2000 share of manufacturing is used in the equations that refer to 2010-2015 and the 1990 share of manufacturing is used in equations that focus on the Great Recession and the pre-Recession periods. ${ }^{14}$

Including manufacturing shares in our models accounts for the general decline in the sector's employment dating to the 1970s, which suggests that more manufacturing-intensive places may be economically struggling. Aside from general manufacturing, labour-intensive manufacturing is particularly exposed to low-wage manufacturing import competition from places such as Vietnam and China (Autor, Dorn and Hanson, 2013[5]), although empirical estimation results for LowWageManufShare are usually statistically

\footnotetext{
${ }^{12}$ For their county-level employment data, EMSI combines various publicly available sources, such as the Bureau of Labor Statistics Quarterly Census of Employment and Wages (QCEW) and others, to fill in values suppressed due to confidentiality concerns ensuring that the final data output is consistent across counties with those reported by industry, occupation, state, and national totals. Several previous studies used the EMSI data (Tsvetkova, Partridge and Betz, 2017[76]). As noted above, the EMSI employment-by-industry data appear to be as accurate if not more accurate than the CBP data if one considers the entire year and not just March when the CBP survey takes place.

${ }^{13}$ The following industries are included in the labour-intensive manufacturing category: NAICS3131 Fiber, Yarn and Thread Mills; NAICS3132 Fabric Mills; NAICS3133 Textile and Fabric Finishing and Fabric Coating Mills; NAICS3141 Textile Furnishings Mills; NAICS3149 Other Textile Product Mills; NAICS3151 Apparel Knitting Mills; NAICS3152 Cut and Sew Apparel Manufacturing; NAICS3159 Apparel Accessories and Other Apparel Manufacturing; NAICS3161 Leather and Hide Tanning and Finishing; NAICS3162 Footwear Manufacturing; NAICS3169 Other Leather and Allied Product Manufacturing; NAICS3371 Household and Institutional Furniture and Kitchen Cabinet Manufacturing; NAICS3372 Office Furniture (including Fixtures) Manufacturing; NAICS3379 Other Furniture Related Product Manufacturing; NAICS3399 Other Miscellaneous Manufacturing.

${ }^{14}$ We use EMSI data for the lagged industry shares for several reasons. First, because the "unsuppressed" CBP data are available starting in 1998, using county employment data by industry from EMSI allows us to calculate the deep lags for 1990. Second, when measuring diversity of a local economy and the relative size of manufacturing, using all industries (including government) allows characterizing the whole local economy, not just its private sector. Given that government jobs can be a sizeable share of employment in many small counties, variables calculated from CBP might introduce non-random measurement error. Finally, using the same data source ensures consistency in how "local economy" is defined, thus the estimation coefficients on the industry composition variables should be internally comparable.
} 
insignificant. ${ }^{15}$ Similarly, to account for susceptibility of a county to differing global and commodity market trends, we control for the deep-lagged 1990/2000 employment shares of agriculture, and mining (these two variables are not reported for brevity). Farm and mining communities are exposed to commodity boom/bust cycles, labour-saving technological change, and technological innovations such as hydraulic fracturing. Because we use deep lags of these variables, EMSI data are used in their calculation.

The SOC vector includes variables that reflect the county's social characteristics. The first is a measure of social capital, SocialCap, using the approach developed by Rupasingha and co-authors (Rupasingha, Goetz and Freshwater, 2006[28]; Rupasingha, Goetz and Freshwater, 2000[27]). The social capital measure is derived from community and individual factors that are related to the propensity of residents to participate in associational activities ${ }^{16}$. Such factors include the county's prevalence of membership organizations, voting in presidential elections, and participating in US Census Bureau surveys. The data source is http://aese.psu.edu/nercrd/community/social-capital-resources for the year that most closely corresponds to each specific model ${ }^{17}$. For example, for the 2010-2015 level equations in (1), we use social capital values in 2009.

Beside the level of human capital, the SOC vector includes education, the 2000 poverty rate and measures of racial/ethnic composition. The educational attainment is measured by the share of adults with less than high school diploma, \%LessHS, and the share of adult population with a bachelor degree or higher, \%BA. There is a long literature that suggests that having a higher initial share of college graduates, for example, is associated with significantly faster local growth in the ensuing decades (Simon, 1998[54]; Simon and Nardinelli, 2002[55]). In particular, we are interested if greater human capital is a positive force in recovering from the Great Recession that improves a local community's resilience after acounting for other local characteristics.

The models include the shares of population that are African-American, Native American, Asian and of other races to account for social and labour market effects (e.g., discrimination). For brevity, we do not report the racial and ethnic variable results. All education and race variables are lagged to mitigate endogeneity concerns, i.e. the 2000 values are used in models covering the $2010-2015$ period. Finally, the 2000 poverty rate is included to test for the effects of poverty, which can also be empirically related to the quality of local institutions. The data for all variables come from the US Decennial Census.

The geographical attributes include distance to the population-weighed centroid of a nearby Metropolitan Statistical Area (MSA) (a distance to the population-weighed centroid of own MSA for metro counties) and incremental distances to MSAs of increasingly larger sizes (population of at least 250, 500 and 1500 thousand in 1990) following the logic of the Central Place Theory as described by Partridge and co-authors (Partridge et al., 2008[56]). The distances are calculated using the ArcGIS software. We include these variables to assess whether access to the urban centre had differential effects post-recession as accessibility is a key feature for rural commuting, while in metro settings, the housing crisis differentially affected exurban and suburban areas. For brevity, we display estimation results for the distance to the nearby MSA, NearMSAkm, only. Proximity to the Great Lakes, Pacific and Atlantic oceans (within 50 miles) is captured by dummies GrtLakes, PacificOcean and AtlanticOcean to reflect their roles as amenities.

\footnotetext{
${ }^{15}$ With manufacturing share included in the model, one needs to be careful in interpreting the low-wage manufacturing share coefficient. It is picking up the difference between the low-wage manufacturing effect and the general manufacturing effect, not whether low-wage manufacturing has a statistically significant effect, which needs to be jointly considered by assessing the effects of both variables.

${ }^{16}$ The index consists of four components and is constructed using principal component analysis. The four components are standardized to have mean zero and standard deviation of one. It is hoped this standardization would minimize potential concerns related to different weights used in index construction over years.
}

${ }^{17}$ The social capital county-level data are available for years 1990, 1997, 2005, 2009 and 2014. 
Using the USDA 1 (low) to 7 (highest) natural amenity classification (https://www.ers.usda.gov/dataproducts/natural-amenities-scale/), we include individual measures for those valued at 4 (average) to 7 (highest) via inclusion of Amenity4, Amenity5, Amenity6 and Amenity7 indicator variables. This allows us to assess the possible changing role of natural amenities such as for Florida and western Sunbelt regions that were hit particularly hard by the housing bust (Carruthers and Mulligan, 2013[57]). For brevity, the amenity variables are not reported in the tables below.

The models also include several common socioeconomic controls used in regional economic analysis. Two population measures account for the effects of agglomeration economies. We include the lagged county population and lagged log population of the nearest (if nonmetro) or own (for metro counties) metropolitan area as reported by the US Census Bureau. Finally, the cross-sectional level models include state fixed effects to factor out unchanging state-level characteristics that may affect county-level social and economic performance.

\section{Differenced equations (OLS and Quantile Regressions)}

Our main model assesses differences between the post-recession expansion and the pre-recession expansion via first-differencing of the dependent and all explanatory variables, except for the deep-lagged variables (which are included in a manner identical to the cross-section specification). The differencing procedure factors out the effects of all time-invariant county-level characteristics that could potentially bias our estimation results in the level model.

Equation (6) is separately estimated for nonmetro and metro subsamples (error terms are clustered at the level of BEA economic areas):

$\Delta Y_{c \tau}=\beta_{0}+\boldsymbol{\beta}_{1} \Delta$ ECON1 $_{c \tau}+\boldsymbol{\beta}_{2} \Delta$ ECON2 $_{c t}+\beta_{3}$ ManufEmp $_{c t}+\beta_{4}$ LowWageManufEmp $_{c t}+$ $\beta_{5} \Delta$ SocialCap $_{c \mathrm{t}}+\boldsymbol{\beta}_{6} \boldsymbol{S O C}_{c \mathrm{t}}+\boldsymbol{\beta}_{7} \boldsymbol{G} \boldsymbol{E} \boldsymbol{O} \boldsymbol{G}_{c}+\boldsymbol{X} \boldsymbol{\beta}+\varepsilon_{c \tau}$

where $c$ denotes county and $\tau$ is the period from time $t$ to time $t 1$. The dependent variables are the first differences (the 2010-2015 period minus the 2000-2007 period) of (a) annualized employment growth rates and (b) average yearly change in poverty rate. The $\triangle E C O N 1$ vector includes IndMix, OccEmpMobility and IndEmpMobility measures differenced over periods corresponding to the differencing of the dependent variables. The $\triangle E C O N 2$ vector includes economic variables that are measured at the beginning of each period and are differenced in accordance with the dependent variable differencing, e.g. 2010 value minus 2000 value for our main specification that compares the post-recession and the pre-recession periods. These variables are JobsFlow and IndDiversity. The deep-lagged shares of manufacturing, low-wage manufacturing, agriculture, and mining are used without transformation.

Among the social characteristics included in the model, only the values of social capital are differenced. All other variables are used in the form identical to Equation (1). The same applies to the geographical attributes that are constant over time. The control variables do not change between Equations (1) and (6) except for the omission of the state fixed effects in the latter because they are differenced away. Because the county fixed effects are factored out, the coefficients in the differenced equations are interpreted as within-county responses to changes in explanatory variables. Table 4.1 lists all variables, provides their brief descriptions and indicates the data sources. 
Table 4.1. Full list of variables and sources

\begin{tabular}{|c|c|c|c|}
\hline Group & Variable & Description & Source \\
\hline \multirow[t]{2}{*}{ Dependent } & AnnEmpGrowth & Annualized employment growth in a county & $\mathrm{CBP}^{*}$ \\
\hline & AvPovRateChange & Average yearly change in poverty rate & SAIPE \\
\hline \multirow[t]{9}{*}{ Economic } & IndMix & $\begin{array}{r}\text { Industry mix term from shift-share analysis; expected growth rate in } \\
\text { a county if all its industries grow at the corresponding national } \\
\text { growth rates }\end{array}$ & $\mathrm{CBP}^{*}$ \\
\hline & JobsFlow & $\begin{array}{r}\text { A measure of how easy it is to find employment in another sector } \\
\text { given county's industrial composition }\end{array}$ & LEHD, CBP* \\
\hline & OccEmpMobility & $\begin{array}{l}\text { A measure of employment share at the end of a period that needs to } \\
\text { shift to another occupation in order for the county's occupational } \\
\text { composition to be the same as at the beginning of a period }\end{array}$ & EMSI \\
\hline & IndEmpMobility & $\begin{array}{r}\text { A measure of employment share at the end of a period that needs to } \\
\text { shift to another industry in order for the county's industrial } \\
\text { composition to be the same as at the beginning of a period }\end{array}$ & $\mathrm{CBP}^{*}$ \\
\hline & IndDiversity & $\begin{array}{r}10,000 \text { minus Herfindahl-Hirschman index calculated for industry } \\
\text { employment shares at the 4-digit NAICS level }\end{array}$ & $\mathrm{CBP}^{*}$ \\
\hline & ManufShare & Share of employment in manufacturing & EMSI \\
\hline & LablntManuf & Share of employment in labour-intensive manufacturing & EMSI \\
\hline & AgriShare & Share of employment in agriculture & EMSI \\
\hline & MiningShare & Share of employment in mining & EMSI \\
\hline \multirow[t]{8}{*}{ Social } & SocialCap & A measure of social capital in a county & $\begin{array}{r}\text { Rupasingha el al. } \\
\left(2006_{[28]}\right)\end{array}$ \\
\hline & $\%$ LessHS & Share of adults with less than high school diploma & US Census \\
\hline & $\% B A$ & Share of adults with BA degree & US Census \\
\hline & \%Black & Share of African-American population & US Census \\
\hline & $\%$ Native & Share of Native American population & US Census \\
\hline & $\%$ Asian & Share of Asian population & US Census \\
\hline & $\%$ Other & Share of other races & US Census \\
\hline & PovRate1960 & Historical poverty rate in 1960 & US Census \\
\hline \multirow[t]{11}{*}{ Geography } & NearMSAkm & Distance to nearby MSA in kilometres & $\begin{array}{l}\text { US Census shape files } \\
\text { processed with ArcGIS }\end{array}$ \\
\hline & PacificOcean & Indicator for counties within 50 mi of Pacific Ocean & $\begin{array}{l}\text { US Census shape files } \\
\text { processed with ArcGIS }\end{array}$ \\
\hline & AtlanticOcean & Indicator for counties within 50 mi of Atlantic Ocean & $\begin{array}{l}\text { US Census shape files } \\
\text { processed with ArcGIS }\end{array}$ \\
\hline & GrtLakes & Indicator for counties within $50 \mathrm{mi}$ of Great Lakes & $\begin{array}{l}\text { US Census shape files } \\
\text { processed with ArcGIS }\end{array}$ \\
\hline & IncDist250 & Incremental distance to MSA of at least 250 thousand in 1990 & $\begin{array}{l}\text { US Census shape files } \\
\text { processed with ArcGIS }\end{array}$ \\
\hline & IncDist500 & Incremental distance to MSA of at least 500 thousand in 1990 & $\begin{array}{l}\text { US Census shape files } \\
\text { processed with ArcGIS }\end{array}$ \\
\hline & IncDist1500 & - Incremental distance to MSA of at least 1500 thousand in 1990 & $\begin{array}{l}\text { US Census shape files } \\
\text { processed with ArcGIS }\end{array}$ \\
\hline & Amenity4 & Level 4 natural amenity index & USDA \\
\hline & Amenity5 & Level 5 natural amenity index & USDA \\
\hline & Amenity6 & Level 6 natural amenity index & USDA \\
\hline & Amenity7 & Level 7 natural amenity index & USDA \\
\hline \multirow[t]{2}{*}{ Controls } & LnMSApop & Log of 1990 size of the nearby (or own for metro counties) MSA & US Census \\
\hline & TotPop & Own county population in 1990 & US Census \\
\hline
\end{tabular}

Note: * ${ }^{\mathrm{CBP}}$ with suppressed data filled using a linear programming algorithm.

Source: The authors. 
The deep-lagged variables have a different interpretation in the first-differenced models. The unchanging level effects of these (and all other constant) variables are differenced away in the fixed effects. What is left is the persistent disequilibrium effects of those variables that would likely decrease over time. That is, if those variable coefficients are statistically insignificant, that does not mean that the variable has no influence because its constant effects over time could be in the fixed effect that are differenced out in the model.

Our last step is to explore the heterogeneity of the effects at different points of the conditional distribution of the response function. In particular, we seek to explore the variations in the statistically significant relationships for high-performing vs. low-performing counties, in which the standard OLS approach produces responses near the mean/median of the distribution. To do so, we re-estimate Equation (6) using quantile regression for the $10^{\text {th }}, 50^{\text {th }}$ and $90^{\text {th }}$ percentiles (we report the $10^{\text {th }}$ and the $90^{\text {th }}$ percentile results only). 


\section{Estimation results and discussion}

We arrange our presentation of results around the two main dependent variables starting with employment growth. The estimation results from all three steps (level and differenced equations followed by quantile regression) are presented together. After the employment growth results, we present corresponding results for average change in the poverty rate.

\section{Employment growth rates}

Figure 5.1 shows the changes in the geographical pattern of job growth before and after the Great Recession. The left panel plots annualized employment growth rate during the 2000-2007 period, while the right panel presents the difference between the pre-recession and the post-recession periods. In the left panel, the darker colours indicate better performance (higher annualised growth rates between 2000 and 2007). In the right panel, darker colours show counties where job growth after the crisis (2010-2015) was greater than their job growth before the crisis (2000-2007). A visual inspection of Figure 5.1 suggests that during the pre-recession expansion, the West tended to perform better together with Texas, Florida and New York. However, when comparing the differences in employment growth in the post- and prerecession periods, there is somewhat of a reversion to the mean. The west of the country fared much worse together with the mid-Atlantic region and Florida after the recession. The spatial patterns of job growth are visually consistent with poverty performance reported in Figure 5.2 in that regions that had less job growth generally had higher poverty rates. The seeming reversal of this pattern in the right-hand-side panel again suggests that the West fared better pre-recession, with the East faring relatively better postrecession. In particular, job growth in the Great Lakes region generally accelerated.

\section{Figure 5.1. Pre- and post-recession employment growth dynamics}

Annualised \% growth for indicated period (left panel) and the difference (right panel)
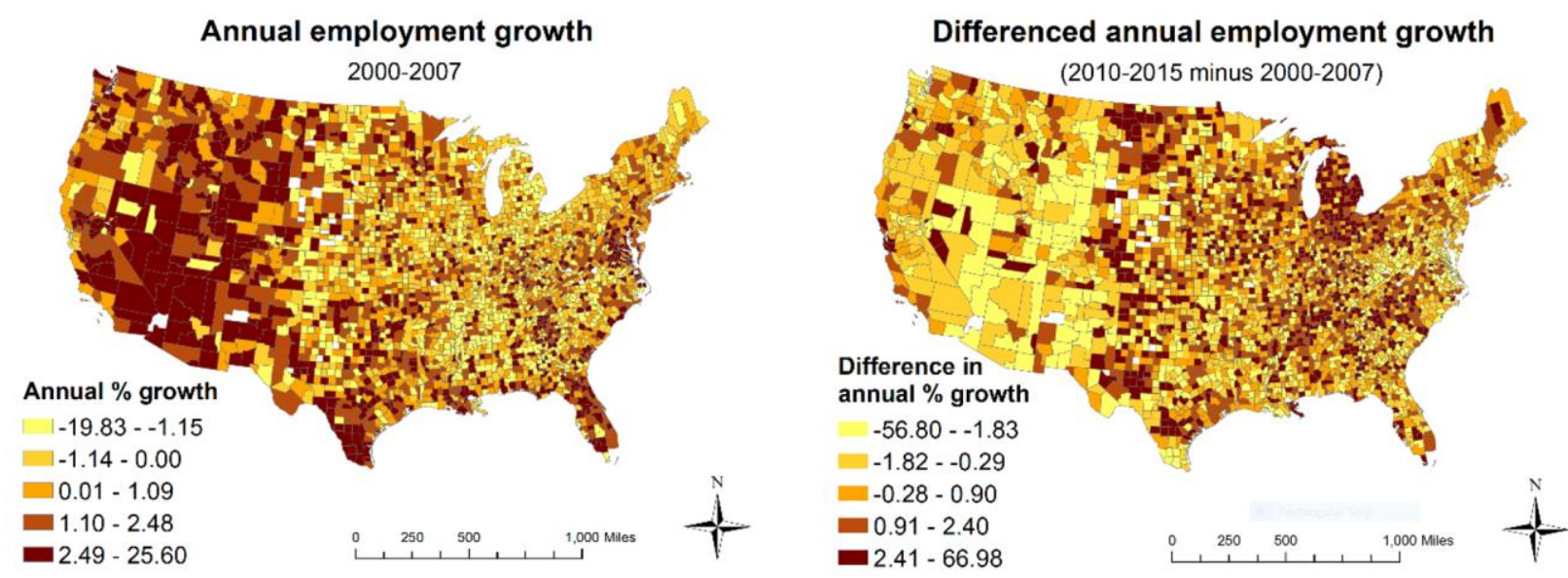

Source: The authors' calculations based on the "unsuppressed" CBP data provided by the W.E. Upjohn Institute for Employment Research. 
Table 5.1 reports estimation results for the cross-section post-recession model and for the differenced model comparing the post- and pre-recession periods. ${ }^{18}$ Again, economic factors emerge as important in determining the employment performance of both metro and nonmetro counties. Local economies that experienced positive demand shocks linked to their industry composition enjoyed greater annual job growth rates. For the level equations results displayed in the left-hand-side panel, employment turnover across occupations and industries (only across industries in the nonmetro sample) are positively related to job growth. Yet, this statistically significant effect only applies to nonmetro counties in the first-difference models between the two expansions (column 3). While the ease for workers to change sectors (JobsFlow) has a statistically insignificant coefficient in the level models, its effects become positive and statistically significant when differencing out the fixed effect (columns 3-4). Conversely, having a greater diversity of industries is statistically insignificant across all models. Manufacturing share is positively related to nonmetro job growth in the 2010-15 equation but when subtracting the pre-recession period, this effect is statistically insignificant. There is no statistical evidence that concentrations of manufacturing reduce employment growth. It is unclear whether this is just a post-recession bounce back but it does not contradict our finding of a negative association between manufacturing and rural poverty.

To summarize estimation results for the economic variables, economic structure that affords more opportunities for labour to change industries and occupations, especially in nonmetro counties, emerges as an important factor for counties to outperform their pre-recession performance in job growth. That is, it seems that economies that more successfully "rewired" are the ones in which it is easiest for workers to shift to growing industries or occupations ${ }^{19}$. This factor appears to be more important than before the crisis. Interestingly enough, after accounting for industry composition using employment shares, as well as for the intensity of employment dynamics and inter-sectoral flows, industrial diversity (commonly believed to be an important determinant of economic growth) is consistently insignificant. Most likely, these results suggest that it is not diversity per se that matters but the degree to which the industrial structure of a local economy facilitates flows of employees and other resources across industries and occupations. ${ }^{20}$

In terms of the social variables, the 2010-2015 level models (columns 1-2) point to a positive relationship between employment growth and higher levels of human capital measured by the share of college graduates. This education result does not hold in the differenced models, perhaps because the impact of human capital is totally captured by the fixed effects (the positive effects stays constant over time). Another interesting observation (estimation results are not shown for brevity) is that the high natural-amenity nonmetro places grew slower during the post-recession period compared to their less-attractive counterparts. This result is consistent with the poverty models and suggests that one possible structural change could be that the $20^{\text {th }}$ century's amenity-led migration (Partridge, 2010[8]) is no longer stoking job growth. However, the amenity results are also consistent with the possibility that high-amenity places (e.g. Florida and California), which suffered larger declines in the quality of life during the Great Recession (Carruthers and Mulligan, 2013 $[57]$ ), had a slower recovery from the housing crash and the Great Recession (at least initially).

\footnotetext{
${ }^{18}$ For the base first difference employment model, the Chow test that the metropolitan coefficients jointly equal the nonmetropolitan coefficients can be rejected at the $99.9 \%$ level of statistical significance.

${ }^{19}$ We also estimated the level and difference models using annualised growth in median household income as the dependent variable. The results suggest an increasing importance of the measures capturing the shifts in the industrial and occupational structure of a local economy. Both OccEmpMobility and IndEmpMobility have positive and statistically significant effects in the rural subsample; only IndEmpMobility has similar effect in the metro sample.

20 This result needs to be verified in other contexts to determine whether it is universal or is specific to the US.
} 
Table 5.1. OLS estimation results for annualised employment growth

\begin{tabular}{|c|c|c|c|c|}
\hline \multirow{2}{*}{ Explanatory variables } & \multicolumn{2}{|c|}{ 2010-2015 } & \multicolumn{2}{|c|}{ 2010-2015 minus $2000-2007$} \\
\hline & Nonmetro & Metro & Nonmetro & Metro \\
\hline IndMix & $0.62^{* \star}(0.30)$ & $0.87^{* *}(0.35)$ & $0.61^{* \star *}(0.22)$ & $1.40^{* \star *}(0.30)$ \\
\hline JobsFlow & $0.35(0.35)$ & $0.66(0.44)$ & $1.60^{* *}(0.63)$ & $1.70^{\star *}(0.76)$ \\
\hline OccEmpMobility & $0.09^{* *}(0.04)$ & $0.18^{* *}(0.07)$ & $0.10^{* \star *}(0.03)$ & $0.02(0.05)$ \\
\hline IndEmpMobility & $0.05^{\star \star *}(0.01)$ & $-0.02(0.03)$ & $0.02^{\star}(0.01)$ & $0.02(0.01)$ \\
\hline IndDiversity & $0.00(0.00)$ & $-0.00(0.00)$ & $-0.00(0.00)$ & $0.00(0.00)$ \\
\hline ManufShare & $3.90^{* \star}(1.57)$ & $0.18(3.08)$ & $2.00(1.97)$ & $-6.40(5.65)$ \\
\hline LowWageManufShare & $0.00(0.02)$ & $0.03(0.04)$ & $0.01(0.02)$ & $0.01(0.03)$ \\
\hline SocialCap & $-0.34^{* *}(0.14)$ & $-0.34^{*}(0.20)$ & $0.24(0.29)$ & $-0.12(0.26)$ \\
\hline$\%$ LessHS & $-0.02(0.03)$ & $-0.04(0.03)$ & $-0.03(0.03)$ & $-0.02(0.03)$ \\
\hline$\% B A$ & $0.14^{* * *}(0.04)$ & $0.11^{* * *}(0.03)$ & $-0.03(0.05)$ & $0.026(0.04)$ \\
\hline PovRat2000 & $-0.01(0.02)$ & $0.02(0.01)$ & $0.02(0.08)$ & $0.06(0.06)$ \\
\hline NearMSAkm & $0.00(0.00)$ & $-0.00(0.01)$ & $0.00(0.00)$ & $-0.00(0.01)$ \\
\hline Constant & $-6.90^{* *}(3.10)$ & $-6.00(10.90)$ & $0.37(0.99)$ & $0.081(1.24)$ \\
\hline Observations & 1986 & 1052 & 1986 & 1052 \\
\hline $\mathrm{R}^{2}$ & 0.198 & 0.267 & 0.130 & 0.147 \\
\hline
\end{tabular}

Note: ${ }^{* * *},{ }^{* *},{ }^{*}$ - significant at $0.01,0.05$, and 0.1 respectively; standard errors clustered at BEA area level in parentheses; all models include a full set of controls as described in the text (AgriShare, MiningShare, IncDist250, IncDist500, IncDist1500, \%Black, \%Native, \%Asian, \%Other, GrtLakes, PacificOcean, AtlanticOcean, Amenity4, Amenity5, Amenity6, Amenity7, LnMSApop, TotPop and state fixed effects in the 2010-2015 equation).

Source: The authors' estimation based on data from multiple sources as described in the text.

We now examine the heterogeneity of the employment responses across better and worse performing counties. To do so, we use the quantile regressions to estimate Equation (6), the first-differenced model. Table 5.2 shows the results.

The IndMix variable, which captures the degree to which the county's industry mix is likely to grow due to the exogenous demand shocks, is positive and strongly significant in both metro and nonmetro counties in the well-performing group (the right panel). Not only do such counties presumably have a faster-growing industry composition, but they get more "bang-per-buck" from their structure, particularly in the metro sample (the estimation coefficient is 1.7 compared to 0.94 for nonmetro). In the case of slow-growers (left panel), only metro counties benefit from a fast-growing industry composition but the coefficient is less than one half of what their better performing counterparts enjoy. Nonmetro poor performers appear to be unable to benefit from a better industry structure, in which they are doubly penalized because such places likely have an unfavourable structure to begin with. Noteworthy, at the $10^{\text {th }}$ percentile, metro and nonmetro county job growth is positively associated with the adaptability and "rewiring" of their economies as measured by the JobsFlow and OccEmpMobility variables.

In terms of economic magnitudes, our results suggest considerable potential gains in terms of employment growth as a result of increasing adaptability of a local economy. One standard deviation of the OccEmpMobility variable is associated with 0.71 greater differenced employment growth in the nonmetro sample, which is (given that the mean value of the differenced employment growth for nonmetropolitan counties is 0.5) an impressive predicted performance improvement. Likewise, one standard deviation increase in the differenced JobsFlow variable appears to increase differenced employment growth by 0.77 in the nonmetro sample and by 0.65 in the metro sample. Thus, (considerably) greater flows among sectors as determined by the industrial structure have the ability - at least as suggested by a linear model - to improve county job growth rates considerably. 
Although further analysis should confirm and validate this assessment, it appears that targeting industrial development by removing barriers to labour flows among sectors is likely to produce better results in lagging areas compared to attempts to increase industrial diversity or to create clusters per se. If a policy approach seeks to augment industrial structure by stimulating and/or attracting industries that would complement the existing composition, our results suggest that prioritising industries, which enjoy greater worker flows (at least in places underperforming in terms of employment growth) bears promise. In practice, policies that focus on industrial composition (within cluster initiatives, for example) predominantly rely on input-output linkages in selecting the focus of attention, which might be not the winning strategy in lagging areas. The possibility that the employment growth mechanisms differ across types of places (and possibly along the urban-rural continuum) could explain why the results of efforts to boost economic fortunes by relying on input-output linkages, clusters, or knowledge spillovers so far produced varied results (Duranton, 2011 [58]; Feser, Renski and Goldstein, 2008[59]). The results of our analysis are in line with a developing literature in evolutionary economics on the nature of industrial recombination in a region (Neffke, Henning and Boschma, 2011[60]; Tsvetkova, Conroy and Thill, 2019[61]; He, Yan and Rigby, 2018[62]).

Table 5.2. Quantile regression results for annualised employment growth, 2010-2015 minus 20002007

\begin{tabular}{l|r|r|r|r}
\hline \multirow{2}{*}{ Explanatory variables } & \multicolumn{2}{|c|}{$10^{\text {th }}$ percentile } & \multicolumn{2}{c}{$90^{\text {th }}$ percentile } \\
\cline { 2 - 5 } & \multicolumn{1}{|c|}{ Nonmetro } & \multicolumn{1}{c}{ Metro } & \multicolumn{1}{c}{ Nonmetro } & \multicolumn{1}{c}{ Metro } \\
\hline IndMix & \multicolumn{1}{c|}{$0.088(0.269)$} & \multicolumn{1}{c}{$0.822^{* *}(0.358)$} & \multicolumn{1}{c}{$0.94^{* *}(0.342)$} & $1.730^{* * *}(0.316)$ \\
\hline JobsFlow & $1.110^{* *}(0.477)$ & $1.140^{*}(0.602)$ & $0.725(0.516)$ & $0.469(0.618)$ \\
\hline OccEmpMobility & $0.066^{* \star *}(0.025)$ & $0.135^{* * *}(0.049)$ & $0.030(0.030)$ & $-0.069(0.050)$ \\
\hline IndEmpMobility & $0.012(0.013)$ & $0.016(0.022)$ & $0.022(0.015)$ & $0.030(0.020)$ \\
\hline IndDiversity & $0.001(0.001)$ & $0.004(0.003)$ & $-0.001(0.001)$ & $0.001(0.002)$ \\
\hline ManufShare & $2.68(2.378)$ & $2.14(3.148)$ & $3.510(2.998)$ & $-3.180(2.486)$ \\
\hline LowWageManufShare & $0.007(0.039)$ & $-0.001(0.044)$ & $-0.035(0.035)$ & $0.026(0.034)$ \\
\hline SocialCap & $-0.237(0.288)$ & $-0.713(0.554)$ & $0.555^{*}(0.293)$ & $-0.115(0.301)$ \\
\hline \%LessHS & $-0.008(0.039)$ & $-0.074(0.060)$ & $0.022(0.034)$ & $-0.064^{*}(0.038)$ \\
\hline \%BA & $-0.024(0.073)$ & $0.076(0.051)$ & $0.062(0.070)$ & $-0.059(0.050)$ \\
\hline PovRate1960 & $-0.076(0.059)$ & $0.192^{* *}(0.086)$ & $-0.006(0.060)$ & $0.086(0.071)$ \\
\hline NearMSAkm & $0.003(0.004)$ & $-0.008(0.013)$ & $0.001(0.004)$ & $-0.02^{* *}(0.009)$ \\
\hline Constant & $-1.29(1.687)$ & $-2.55(1.694)$ & $0.502(1.455)$ & $2.39^{*}(1.420)$ \\
\hline Observations & 1986 & 1052 & 1986 & 1052 \\
\hline Pseudo R2 & 0.110 & 0.220 & 0.133 & \\
\hline
\end{tabular}

Note: ${ }^{* * *},{ }^{* *},{ }^{*}$ - significant at $0.01,0.05$, and 0.1 respectively; standard errors clustered at BEA area level in parentheses; all models include a full set of controls as described in the text (AgriShare, MiningShare, IncDist250, IncDist500, IncDist1500, \%Black, \%Native, \%Asian, \%Other, GrtLakes, PacificOcean, AtlanticOcean, Amenity4, Amenity5, Amenity6, Amenity7, LnMSApop, TotPop and state fixed effects in the 2010-2015 equation).

Source: The authors' estimation based on data from multiple sources as described in the text.

\section{Change in poverty rates}

Figure 5.2 shows geographical distribution of the 2000-2007 average poverty rate change (left panel) and of the post-recession dynamics (2010-2015) relative to the presented pre-recession trends (right panel). A visual inspection of Figure 5.2 suggests that during the pre-recession expansion, the West tended to perform better with a modest decrease or no change in poverty (except for counties in Washington and Oregon, as well as in the southwest part of the West North Central Census division), with the mid-Atlantic region and Florida also faring well. When comparing the differences in poverty rate changes in the post- 
and pre-recession periods, there is again a pattern of the reversion to the mean already observed on the employment growth maps in Figure 5.1. The West of the country fared much worse together with the midAtlantic region and Florida after the recession. While the East performed much better in general, the persistently poor regions such as the Mississippi Delta, southeastern Black belt, and central Appalachia fared worse in both the pre- and post-Great Recession expansions. Yet, the perception that manufacturingcentred regions in the Rustbelt performed poorly after the recession is not supported at least in terms of poverty rates.

\section{Figure 5.2. Pre- and post-recession poverty dynamics}

Average change for indicated period (left panel) and the difference (right panel)
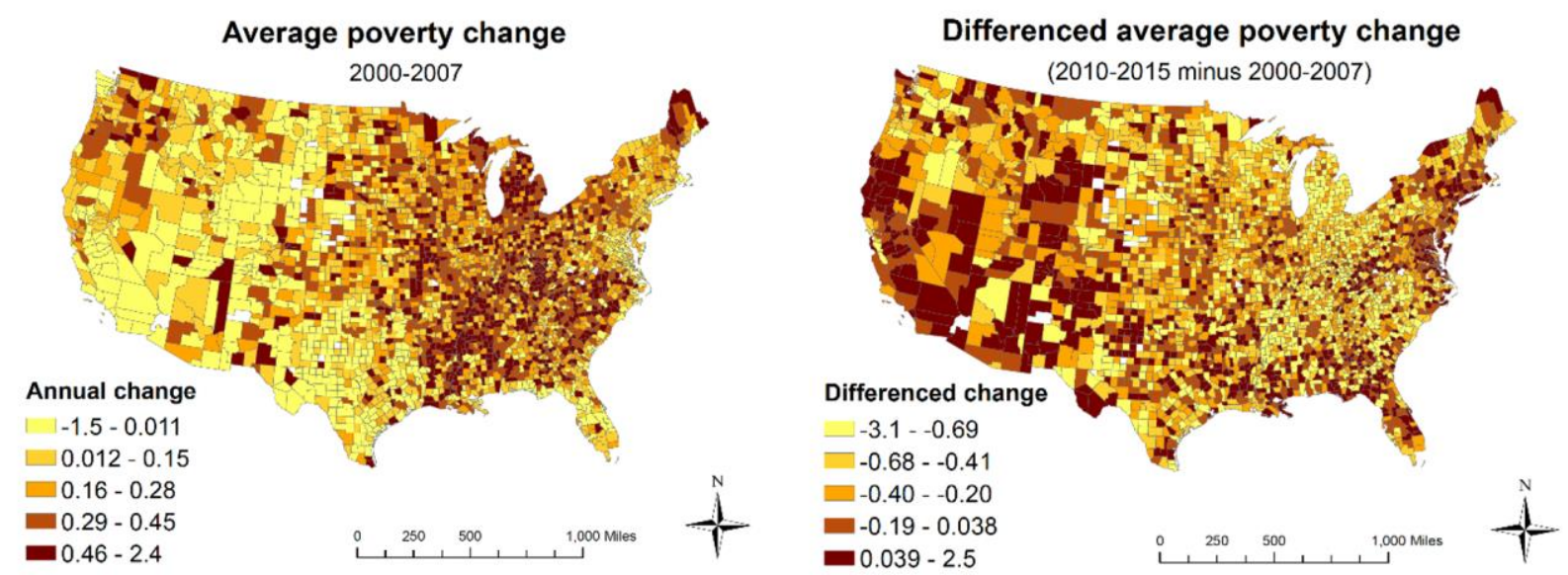

Source: The authors' calculations based on the "unsuppressed" CBP data provided by the W.E. Upjohn Institute for Employment Research.

The empirical analysis for the cross-section level model and the first-difference model is presented in Table $1{ }^{21}$ The results point to differing effects of the three variable groupings. What stands out in both the postrecession level model and the first-difference models is the important role of whether a county experienced favourable (unfavourable) demand shocks associated with a fast-growing (or slow-growing) industry composition (IndMix). However, in some sense, because of the difficulty to change an area's industry composition, the ability of policymakers to influence local poverty in the short-to-medium term is likely to be limited.

Rural economies tend to lack the scale that typically leads to better labour market matching found in large cities (Rosenthal and Strange, 2004[63]). Thus, it seems more likely that having more industry and occupational job mobility would relate to lower rural poverty. Industry mobility is especially associated with lower nonmetro poverty rates in the level models, consistent with positive rewiring effects or resilience. However, in the level models, greater occupational mobility is related to increases in the 2010-2015 poverty rates, indicating that at least at the bottom of the income distribution (where labour mobility is able to affect poverty rates), occupational mobility is likely to reflect downward moves implying lower pay and worse aggregate performance in terms of poverty measures. In both the metro and nonmetro cross-section models, the other labour-market dynamic variables are statistically insignificant except that greater industry diversity is associated with lower metro poverty over the 2010-2015 period (column 2, only weakly significant). In the first-difference models, the dynamic variables are statistically insignificant except for

\footnotetext{
${ }^{21}$ Regarding the base first difference poverty models, the Chow test rejects the joint null that the metropolitan coefficients equal the nonmetropolitan coefficients at the $95 \%$ level.
} 
greater occupation mobility is associated with greater reductions in metro poverty rates between the two economic expansions (column 4).

Contrary to what may be expected, greater manufacturing share in nonmetro counties is negatively related to poverty rates in both the cross-sectional model (column 1) and in the change between the two economic expansions (column 3). One likely explanation is that manufacturing sustained a modest bounce back after the recession that especially helped nonmetro low-wage households. Yet, a greater share of low-wage manufacturing is statistically insignificant, suggesting that any poverty-reducing effects are general to all of manufacturing.

Turning to the other social/demographic attributes, social capital is insignificant, while historical poverty levels tend to be related to decreased poverty change. Places with greater levels of human capital measured by the share of college graduates enjoyed decrease/smaller increase in metro and nonmetro poverty. A somewhat unexpected result is a statistically significant negative association between the share of adults with less than high school degree and average poverty rate in metro counties.

Regarding the geography variables, being closer to metropolitan areas is associated with higher nonmetropolitan poverty, which is inconsistent with Partridge and Rickman $\left(2008_{[64]}\right)$ and may reflect troubles in exurban areas as a result of the housing crash. Similarly, being farther away from the metropolitan core is associated with higher metro poverty in the first-difference metro model (column 4), further suggesting that poor exurban metro households struggled in the wake of the Great Recession and housing bust, though it is not clear if this is a permanent effect. Finally, when considering the relative change in poverty between the two economic expansions (columns 3-4), higher natural amenities are generally related to relatively higher poverty in the latter period, suggesting that those areas were struggling to recover.

Table 5.3. OLS estimation results for average change in poverty

\begin{tabular}{|c|c|c|c|c|}
\hline \multirow[t]{3}{*}{ Explanatory variables } & \multicolumn{4}{|c|}{ Poverty rate change } \\
\hline & \multicolumn{2}{|c|}{ 2010-2015 } & \multicolumn{2}{|c|}{ 2010-2015 minus 2000-2007 } \\
\hline & Nonmetro & Metro & Nonmetro & Metro \\
\hline IndMix & $-0.07^{* \star}(0.03)$ & $-0.08^{\star * *}(0.03)$ & $-0.046^{\star * *}(0.02)$ & $-0.10^{* * *}(0.02)$ \\
\hline JobsFlow & $-0.04(0.02)$ & $0.006(0.03)$ & $-0.04(0.03)$ & $0.021(0.03)$ \\
\hline OccEmpMobility & $0.005^{\star \star}(0.00)$ & $0.002(0.00)$ & $0.002(0.00)$ & $-0.007^{\star \star \star}(0.00)$ \\
\hline IndEmpMobility & $-0.001^{* *}(0.00)$ & $0.001(0.00)$ & $0.001(0.00)$ & $-0.001(0.00)$ \\
\hline IndDiversity & $-0.00(0.00)$ & $-0.00^{*}(0.00)$ & $0.00(0.00)$ & $0.00(0.00)$ \\
\hline ManufShare & $-0.37^{* \star}(0.17)$ & $-0.031(0.17)$ & $-0.47^{* * *}(0.18)$ & $-0.15(0.22)$ \\
\hline LowWageManufShare & $-0.004(0.00)$ & $-0.007^{\star}(0.00)$ & $0.001(0.00)$ & $-0.004(0.00)$ \\
\hline SocialCap & $0.007(0.01)$ & $0.02(0.01)$ & $-0.00(0.02)$ & $-0.02(0.02)$ \\
\hline$\%$ LessHS & $-0.006(0.00)$ & $-0.007^{* *}(0.00)$ & $-0.00(0.00)$ & $0.001(0.00)$ \\
\hline$\% \mathrm{BA}$ & $-.012^{\star * *}(0.00)$ & $-0.008^{* *}(0.00)$ & $-0.014^{* *}(0.01)$ & $-0.013^{\star \star}(0.01)$ \\
\hline PovRate2000 & $0.002(0.00)$ & $0.002(0.00)$ & $-0.001^{*}(0.01)$ & $-0.016^{\star \star}(0.01)$ \\
\hline NearMSAkm & $-0.006^{* *}(0.00)$ & $0.001(0.00)$ & $-0.00(0.00)$ & $0.003^{* * *}(0.00)$ \\
\hline Constant & $0.76^{* \star}(0.31)$ & $0.63^{\star *}(0.28)$ & $-0.032(0.14)$ & $-0.11(0.15)$ \\
\hline Observations & 1986 & 1052 & 1986 & 1052 \\
\hline $\mathrm{R}^{2}$ & 0.165 & 0.199 & 0.085 & 0.155 \\
\hline
\end{tabular}

Note: ${ }^{* *},{ }^{* *},{ }^{*}$ - significant at $0.01,0.05$, and 0.1 respectively; standard errors clustered at BEA area level in parentheses; all models include a full set of controls as described in the text (AgriShare, MiningShare, IncDist250, IncDist500, IncDist1500, \%Black, \%Native, \%Asian, \%Other, GrtLakes, PacificOcean, AtlanticOcean, Amenity4, Amenity5, Amenity6, Amenity7, LnMSApop, TotPop and state fixed effects in the 2010-2015 equation).

Source: The authors' estimation based on data from multiple sources as described in the text. 
To explore possible heterogeneity across counties with various poverty dynamics, we re-estimate Equation (6) using quantile regression. Table 5.4 shows estimation results for the 10 th and 90 th percentiles. Unlike Table 5.2 where results for the stronger performing counties are displayed in the right panel, results for the stronger performers in terms of poverty are in the right-hand-side panel. In other words, the $10^{\text {th }}$ percentile results reflect the strongest economic performers in terms of change in poverty rates (lower poverty), while the $90^{\text {th }}$ percentile results are for counties that suffered the largest poverty increases. For the most part, these results suggest that at the tails of the poverty rate distribution, the general pattern is one of statistically insignificant coefficients, meaning that at the tails, the reasons for their relative post-recession performance are mainly idiosyncratic.

A couple key results are unchanged. One is that for the lowest part of the poverty change distribution (counties that are more well-off economically), demand shocks related to their industry mix is negatively related to nonmetro poverty. Likewise, IndMix remains negative and statistically significant in both the metro and nonmetro samples at the $50^{\text {th }}$ percentile (not reported). Thus, industry composition's positive effects on the ability of a locality to reduce poverty are clearest at the middle of metro distribution and in the lower half (counties more successful in reducing poverty) of the nonmetro distribution. Moreover, a concentration of nonmetro manufacturing is negatively related to poverty in at both ends of the distribution. Consistent with the OLS results, higher levels of college graduates are associated with lower metro poverty at both the $10^{\text {th }}$ and $90^{\text {th }}$ percentile, although in the former case the coefficient is significant at the 0.1 level only. Finally, though it is weaker in the metro case, locations with high natural amenities tend to have higher poverty rates, especially in less poverty-ridden counties.

Table 5.4. Quantile regression results for average poverty change, 2010-2015 minus 2000-2007

\begin{tabular}{|c|c|c|c|c|}
\hline \multirow[t]{2}{*}{ Explanatory variables } & \multicolumn{2}{|c|}{$10^{\text {th }}$ percentile } & \multicolumn{2}{|c|}{$90^{\text {th }}$ percentile } \\
\hline & Nonmetro & Metro & Nonmetro & Metro \\
\hline IndMix & $-0.051^{* *}(0.020)$ & $-0.105^{\star}(0.055)$ & $-0.019(0.027)$ & $-0.043(0.039)$ \\
\hline JobsFlow & $-0.037(0.041)$ & $0.038(0.068)$ & $-0.041(0.042)$ & $0.068(0.048)$ \\
\hline OccEmpMobility & $0.004^{*}(0.002)$ & $-0.006(0.006)$ & $0.001(0.002)$ & $-0.008^{* *}(0.004)$ \\
\hline IndEmpMobility & $0.001(0.001)$ & $-0.001(0.002)$ & $-0.001(0.001)$ & $0.000(0.001)$ \\
\hline IndDiversity & $-0.000(0.000)$ & $-0.000(0.000)$ & $0.000(0.000)$ & $0.000(0.000)$ \\
\hline ManufShare & $-0.593^{* *}(0.278)$ & $-0.209(0.505)$ & $-0.59^{\star \star \star}(0.217)$ & $-0.105(0.286)$ \\
\hline LowWageManufShare & $-0.002(0.005)$ & $-0.007(0.007)$ & $0.004(0.004)$ & $-0.003(0.007)$ \\
\hline SocialCap & $0.003(0.027)$ & $0.057(0.050)$ & $-0.042(0.027)$ & $-0.067^{*}(0.037)$ \\
\hline \%LessHS & $-0.005(0.003)$ & $0.002(0.006)$ & $0.000(0.004)$ & $0.003(0.004)$ \\
\hline$\% B A$ & $-0.015^{*}(0.008)$ & $-0.031^{* * *}(0.010)$ & $-0.008(0.007)$ & $-0.011^{*}(0.006)$ \\
\hline PovRate2000 & $-0.03^{\star * *}(0.006)$ & $-0.069^{\star * *}(0.013)$ & $0.025^{* * *}(0.007)$ & $0.016^{* *}(0.007)$ \\
\hline NearMSAkm & $-0.000(0.000)$ & $0.003^{\star *}(0.001)$ & $-0.000(0.000)$ & $0.004^{* * *}(0.001)$ \\
\hline Constant & $0.122(0.167)$ & $-0.069(0.237)$ & $0.067(0.167)$ & $-0.193(0.161)$ \\
\hline Observations & 1986 & 1052 & 1986 & 1052 \\
\hline Pseudo R² & 0.137 & 0.180 & 0.116 & 0.153 \\
\hline
\end{tabular}

Note: ${ }^{* * *},{ }^{* *},{ }^{*}$ - significant at $0.01,0.05$, and 0.1 respectively; standard errors clustered at BEA area level in parentheses; all models include a full set of controls as described in the text (AgriShare, MiningShare, IncDist250, IncDist500, IncDist1500, \%Black, \%Native, \%Asian, \%Other, GrtLakes, PacificOcean, AtlanticOcean, Amenity4, Amenity5, Amenity6, Amenity7, LnMSApop, TotPop and state fixed effects in the 2010-2015 equation).

Source: The authors' estimation based on data from multiple sources as described in the text.

Overall, our poverty results suggest that a locality's industry composition is one of the most important determinants in alleviating poverty. In the differenced analysis, which is our main focus, the industry mix term and manufacturing shares in nonmetro counties are more important in reducing poverty after the recession compared to the pre-recession expansion, although the IndMix variable seems less relevant in 
the group of counties with the largest relative increase in poverty. The effects of the industrial structure do not change between the pre-recession and the post-recession period in counties that were less successful in reducing poverty. On the other hand, occupational mobility is increasingly important in combating poverty the metro subsample of such counties. In terms of economic effects of the local economic flexibility measures in the main (differenced) models, it appears that one standard deviation increase in OccEmpMobility is associated with additional $0.035 \%$ decrease in average poverty rate for metropolitan areas, which is more than $10 \%$ performance improvement for an average metro county in terms of poverty reduction. 


\section{Conclusions and policy implications}

In this article we explore how various economic, social, and geography factors influence US county economic well-being in the $21^{\text {st }}$ century. We do this by splitting the sample into three periods: pre-recession, recession and post-recession. Using a combination of cross-sectional, first-difference, and quantile regression analyses, we study the changes in the effects (that possibly occurred during or since the Great Recession) on job growth and the change in poverty rates in rural and urban counties. In addition to focusing on the role played by the existing industry structure (and in particular whether it consists of industries that are expanding nationally) and other traditional determinants, we consider several relatively novel measures of labour-market "rewiring" ability, which capture how much local areas (can) reallocate workers across industries and occupations.

We present descriptive evidence that suggests that the East's performance during the post-recession expansion improved relative to the pre-recession expansion (including in the Rustbelt). Our empirical results suggest that through the three periods considered, factors related to the industrial structure are important determinants of economic well-being. The primary factor that is almost universally associated with lower poverty and greater job growth is the industrial structure that consists of industries growing nationally (a positive demand shock). Our estimation indicates, however, that the positive effects of a (positive) demand shock are observable only for places that are at the middle or the higher end of economic performance distribution (more well-off locations). Counties that are lagging behind are generally detached from the national growth processes.

The variables that are central to our analysis and approximate the "rewiring" ability appear to be most important at the lower end of the economic performance distribution (and in rural areas). Conversely, there is practically no evidence that having a more diverse industry structure positively affects outcomes, suggesting that once labour-market mobility is accounted for, there is little left for diversity to explain. Especially at the lower end of the distribution in terms of job growth, the ability of counties to reallocate labour (to rewire) is an important factor behind better performance since the Great Recession.

For policymakers these findings imply that once a location's industry composition is set, it is hard to alter its economic growth path. On the positive side, however, there is evidence that counties exhibiting greater "rewiring" ability of their economies, measured by the shifts in employment across industries and occupations or by the propensity of the local industrial structure to accommodate higher inter-sectoral job flows, often performed better after the recession (especially in rural areas). This result has important policy implications. Rather than simple diversification efforts or efforts to build clusters, our findings suggest that lagging areas should try to encourage labour flows, ideally from lower- to better- performing sectors, industries and firms.

This conclusion is in line with a long-standing debate on labour market flexibility and its economic effects (Martin and Scarpetta, 2012[65]; Nicoletti and Scarpetta, 2003[66]). Many factors can potentially influence the propensity of the local economy to adjust by reallocating workers across industries and occupations. 
The regulatory environment is one of the most-studied ones. While regulations can be hard to considerably revise and seamlessly implement, especially within a relatively short period, new technology adoption can offer more immediate beneficial effects. Encouraging technology uptake among companies, in particular SMEs, can help enhance adaptability of the workers, firms and local economies overall.

Of demographic factors, the positive effect of higher human capital was only modestly confirmed. While more research is needed, the results suggest a smaller role for human capital in determining economic growth. Of course, this could represent some of the adjustment coming out of the Great Recession and may change. On the other hand, the results can point to the changing nature of the human capital that matters. The commonly used measure also adopted in this analysis, a share of adults with at least a college degree, may become less relevant while the importance of specific types of education, for example, STEM or technology use, can be of growing importance. The positive effects of natural amenities observed in the $20^{\text {th }}$ century as documented in the literature are mostly reversed during the Great Recession and after, pointing to the limitations of reliance on natural amenity-led development in US counties. In addition, the decline of amenity-led growth in the $21^{\text {st }}$ century may suggest that at least in terms of spatial equilibrium, amenity migration may have run its course.

To summarise, we find that the structural changes in the effects of the factors shaping employment growth and poverty change in the US counties are relatively modest. We also document a post-recession shift toward economic factors such as industry composition and away from human capital and amenity-led growth. Among economic factors, the ability of local economies to adapt by shifting employees across industries and occupations emerges as increasingly important factor including in the rural counties and counties that are less well-off in terms of economic performance. 


\section{References}

Adamy, J. and P. Overberg (2017), Rural America Is the New 'Inner City', https://www.wsj.com/articles/rural-america-is-the-new-inner-city-1495817008 (accessed on 31 March 2020).

Akçomak, I. and B. ter Weel (2009), "Social capital, innovation and growth: Evidence from Europe", European Economic Review, Vol. 53/5, pp. 544-567, http://dx.doi.org/10.1016/..euroecorev.2008.10.001.

Amcoff, J. and E. Westholm (2007), "Understanding rural change-demography as a key to the future", Futures, Vol. 39/4, pp. 363-379, http://dx.doi.org/10.1016/.futures.2006.08.009.

Andersson, M. and H. Lööf (2011), "Agglomeration and productivity: Evidence from firm-level data", Annals of Regional Science, Vol. 46/3, pp. 601-620, http://dx.doi.org/10.1007/s00168$\underline{009-0352-1 .}$.

Autor, D., D. Dorn and G. Hanson (2013), "The China syndrome: Local labor market effects of import competition in the United States", American Economic Review, Vol. 103/6, pp. 2121 2168, http://dx.doi.org/10.1257/aer.103.6.2121.

Autor, D., L. Katz and M. Kearney (2008), Trends in U.S. wage inequality: Revising the revisionists, The MIT Press, http://dx.doi.org/10.1162/rest.90.2.300.

Barro, R. and X. Sala-I-Martin (1990), "Economic growth and convergence across the United States", National Bureau of Economic Research, No. 3419, http://dx.doi.org/10.3386/w3419.

Bartik, T. (1991), Who Benefits from State and Local Economic Development Who Benefits from State and Local Economic Development Policies? Policies?, W.E. Upjohn Institute for Employment Research, Kalamazoo, MI, https://research.upjohn.org/up press (accessed on 31 March 2020).

Bertrand, M., E. Duflo and S. Mullainathan (2004), "How much should we trust differences-indifferences estimates?", The Quarterly Journal of Economics, Vol. 119/1, pp. 249-275, http://dx.doi.org/10.1162/003355304772839588.

Betz, M. and L. Jones (2018), "Wage and employment growth in America's drug epidemic: Is all growth created equal?", American Journal of Agricultural Economics, Vol. 100/5, pp. 13571374, https://academic.oup.com/ajae/article-abstract/100/5/1357/5095194 (accessed on 27 March 2020).

Betz, M. and M. Partridge (2013), "Country road take me home: Migration patterns in Appalachian America and place-based policy", International Regional Science Review, Vol. 36/3, pp. 267-295, http://dx.doi.org/10.1177/0160017612467646.

Beyers, W. (2013), "The Great Recession and state unemployment trends", Economic Development Quarterly, Vol. 27/2, pp. 114-123, http://dx.doi.org/10.1177/0891242413479653.

Brezzi, M., L. Dijkstra and V. Ruiz (2011), "OECD Extended Regional Typology: The economic performance of remote rural regions", OECD Regional Development Working Papers, No. 2011/06, OECD, Paris, http://dx.doi.org/10.1787/5kg6z83tw7f4-en. 
Camagni, R. (2009), "Territorial capital and regional development", in Capello, R. and P. Nijkamp (eds.), Handbook of Regional Growth and Development Theories, Edward Elgar, Cheltenham, UK.

Carlino, G. and L. Mills (1996), "Testing neoclassical convergence in regional incomes and earnings", Regional Science and Urban Economics, Vol. 26/6 SPEC. ISS., pp. 565-590, http://dx.doi.org/10.1016/S0166-0462(96)02137-0.

Carlino, G. and L. Mills (1993), "Are U.S. regional incomes converging?. A time series analysis", Journal of Monetary Economics, Vol. 32/2, pp. 335-346, http://dx.doi.org/10.1016/03043932(93)90009-5.

Carruthers, J. and G. Mulligan (2013), "Through the crisis", Economic Development Quarterly, Vol. 27/2, pp. 124-143, http://dx.doi.org/10.1177/0891242413485812.

Case, A. and A. Deaton (2015), "Rising morbidity and mortality in midlife among white non[68] Hispanic Americans in the 21st century", Proceedings of the National Academy of Sciences of the United States of America, Vol. 112/49, pp. 15078-15083, http://dx.doi.org/10.1073/pnas.1518393112.

Caselli, F. and W. Coleman (2001), "The U.S. structural transformation and regional convergence: A reinterpretation”, Journal of Political Economy, Vol. 109/3, pp. 584-616, http://dx.doi.org/10.1086/321015.

Center for American Progress (2018), Bold Ideas for State Action, https://www.americanprogress.org/issues/general/reports/2018/05/10/450580/bold-ideasstate-action/ (accessed on 27 March 2020).

Deller, S., V. Lledo and D. Marcouiller (2008), "Modeling regional economic growth with a focus on amenities", Review of Urban \& Regional Development Studies, Vol. 20/1, pp. 1-21, http://dx.doi.org/10.1111/j.1467-940X.2008.00139.x.

Deller, S. et al. (2001), "The role of amenities and quality of life In rural economic growth", American Journal of Agricultural Economics, Vol. 83/2, pp. 352-365, http://dx.doi.org/10.1111/0002-9092.00161.

Duranton, G. (2011), California Dreamin': The Feeble Case for Cluster Policies, http://www.clusters2009.com/. (accessed on 1 April 2020).

Easterly, W. (2001), The elusive quest for growth : Economists' adventures and misadventures in the tropics, MIT Press, Cambridge, MA.

Ellis, M., R. Wright and V. Parks (2004), "Work Together, Live Apart? Geographies of Racial and Ethnic Segregation at Home and at Work", Annals of the Association of American Geographers, Vol. 94/3, pp. 620-637, http://dx.doi.org/10.1111/j.1467-8306.2004.00417.x.

Elsby, M., B. Hobijn and A. Sahin (2010), "The Labor Market in the Great Recession", NBER Working Paper, No. 15979, National Bureau of Economic Research, Cambridge, MA, http://dx.doi.org/10.3386/w15979.

Elsby, M., B. Hobijn and A. Şahin (2013), "The decline of the U.S. labor share", Brookings Papers on Economic Activity, Vol. 2013/FALL 2013, pp. 1-52, http://dx.doi.org/10.1353/eca.2013.0016. 
Faggian, A. and P. Mccann (2009), "Human capital, graduate migration and innovation in British regions", Cambridge Journal of Economics, Vol. 33, pp. 317-333, http://dx.doi.org/10.1093/cje/ben042.

Fallah, B., M. Partridge and D. Rickman (2014), "Geography and high-tech employment growth in US counties", Journal of Economic Geography, Vol. 14/4, pp. 683-720, http://dx.doi.org/10.1093/jeg/lbt030.

Fan, C. and E. Casetti (1994), "The spatial and temporal dynamics of US regional income inequality, 1950-1989", The Annals of Regional Science, Vol. 28/2, pp. 177-196, http://dx.doi.org/10.1007/BF01581768.

Feser, E., H. Renski and H. Goldstein (2008), "Clusters and economic development outcomes", Economic Development Quarterly, Vol. 22/4, pp. 324-344, http://dx.doi.org/10.1177/0891242408325419.

Florida, R. (2009), How the Crash Will Reshape America, https://www.theatlantic.com/magazine/archive/2009/03/how-the-crash-will-reshapeamerica/307293/ (accessed on 31 March 2020).

Fodor, E. (2012), "Relationship between growth and prosperity in the 100 largest U.S. metropolitan areas", Economic Development Quarterly, Vol. 26/3, pp. 220-230, http://dx.doi.org/10.1177/0891242412452782.

Foster, L., C. Grim and J. Haltiwanger (2016), "Reallocation in the great recession: Cleansing or not?", Journal of Labor Economics, Vol. 34/S1, pp. S293-S331, http://dx.doi.org/10.1086/682397.

Glaeser, E. and J. Gottlieb (2009), "The wealth of cities: Agglomeration economies and spatial equilibrium in the United States", Journal of Economic Literature, Vol. 47/4, pp. 983-1028, http://dx.doi.org/10.1257/jel.47.4.983.

Glaeser, E. and J. Gottlieb (2008), "The economics of place-making policies", Brookings Papers of Economic Activity, Vol. 1/Spring, pp. 155-239, http://scholar.harvard.edu/gottlieb/publications/economics-place-making-policies (accessed on 2 August 2019).

Goetz, S. and D. Hu (1996), "Economic growth and human capital accumulation: Simultaneity and expanded convergence tests", Economics Letters, Vol. 51/3, pp. 355-362, http://dx.doi.org/10.1016/0165-1765(96)00827-0.

Gore, C. (2010), "The global recession of 2009 in a long-term development perspective", Journal of International Development, Vol. 22/6, pp. 714-738, http://dx.doi.org/10.1002/jid.1725.

Green, G., S. Deller and D. Marcouiller (eds.) (2005), Amenities and rural development : theory, methods and public policy, Edward Elgar, Northampton, MA.

Hammond, G. and E. Thompson (2004), "Employment risk in U.S. metropolitan and nonmetropolitan regions: The influence of industrial specialization and population characteristics", Journal of Regional Science, Vol. 44/3, pp. 517-542, http://dx.doi.org/10.1111/j.0022-4146.2004.00347.x.

He, C., Y. Yan and D. Rigby (2018), "Regional industrial evolution in China", Papers in Regional [62] Science, Vol. 97/2, pp. 173-198, http://dx.doi.org/10.1111/pirs.12246. 
Isserman, A. and J. Westervelt (2006), "1.5 million missing numbers: Overcoming employment suppression in County Business Patterns data", International Regional Science Review, Vol. 29/3, pp. 311-335, http://dx.doi.org/10.1177/0160017606290359.

Khatiwada, L. (2014), Modeling and Explaining County-level Prosperity in the U.S, https://jrap.scholasticahq.com/article/7895.pdf (accessed on 30 March 2020).

Lagravinese, R. (2015), "Economic crisis and rising gaps North-South: evidence from the Italian regions", Cambridge Journal of Regions, Economy and Society, Vol. 8/2, pp. 331-342, http://dx.doi.org/10.1093/cjres/rsv006.

Levernier, W., M. Partridge and D. Rickman (2000), "The causes of regional variations in U.S. poverty: A cross-county analysis", Journal of Regional Science, Vol. 40/3, pp. 473-497, http://dx.doi.org/10.1111/0022-4146.00184.

Lowrey, A. (2017), How the Great Recession Continues to Shape America, https://www.theatlantic.com/business/archive/2017/12/great-recession-still-with-us/547268/ (accessed on 27 March 2020).

Lucas, R. (1989), "On the Mechanics of Economic Development”, NBER Working Paper, No. R1176, NBER, Cambridge, MA.

Martin, J. and S. Scarpetta (2012), Setting it right: Employment protection, labour reallocation and productivity, Springer, http://dx.doi.org/10.1007/s10645-011-9177-2.

Martin, R. et al. (2016), "How regions react to recessions: Resilience and the role of economic structure", Regional Studies, Vol. 50/4, pp. 561-585, http://dx.doi.org/10.1080/00343404.2015.1136410.

Martin, R., P. Sunley and P. Tyler (2015), "Local growth evolutions: recession, resilience and recovery”, Cambridge Journal of Regions, Economy and Society, Vol. 8/2, pp. 141-148, http://dx.doi.org/10.1093/cjres/rsv012.

Meara, E. and J. Skinner (2015), Losing ground at midlife in America, National Academy of Sciences, http://dx.doi.org/10.1073/pnas.1519763112.

Moscarini, G. and F. Postel-Vinay (2016), "Did the job ladder fail after the great recession?", Journal of Labor Economics, Vol. 34/S1, pp. S55-S93, http://dx.doi.org/10.1086/682366.

Neffke, F., M. Henning and R. Boschma (2011), "How do regions diversify over time? Industry relatedness and the development of new growth paths in regions", Economic Geography, Vol. 87/3, pp. 237-265, http://dx.doi.org/10.1111/j.1944-8287.2011.01121.x.

Nelson, R. and E. Phelps (1966), "Investment in humans, technological diffusion, and economic growth", The American Economic Review, Vol. 56/1, pp. 69-75, https://www.jstor.org/stable/1821269 (accessed on 31 March 2020).

Nicoletti, G. and S. Scarpetta (2003), "Regulation , productivity and growth: OECD evidence", Economic Policy 36, pp. 9-72, http://dx.doi.org/10.1111/1468-0327.00102.

Partridge, M. (2010), "The duelling models: NEG vs amenity migration in explaining US engines of growth", Papers in Regional Science, Vol. 89/3, pp. 513-537, http://dx.doi.org/10.1111/j.1435-5957.2010.00315.x. 
Partridge, M. et al. (2007), "Riding the wave of urban growth in the countryside: Spread, backwash, or stagnation?", Land Economics, Vol. 83/2, pp. 128-152, http://le.uwpress.org/content/83/2/128.full.pdf (accessed on 7 December 2018).

Partridge, M. and D. Rickman (2008), "Distance from urban agglomeration economics and rural poverty", Journal of Regional Science, Vol. 48/2, pp. 285-310, http://dx.doi.org/10.1111/i.1467-9787.2008.00552.x.

Partridge, M. and D. Rickman (2005), "High-poverty nonmetropolitan counties in America: Can economic development help?", International Regional Science Review, Vol. 28/4, pp. 415440, http://dx.doi.org/10.1177/0160017605278998.

Partridge, M. et al. (2009), "Agglomeration spillovers and wage and housing cost gradients across the urban hierarchy", Journal of International Economics, Vol. 78/1, pp. 126-140, http://dx.doi.org/10.1016/j.jinteco.2009.02.004.

Partridge, M. et al. (2008), "Lost in space: Population growth in the American hinterlands and small cities", Journal of Economic Geography, Vol. 8/6, pp. 727-757, http://dx.doi.org/10.1093/jeg//bn038.

Putnam, R., R. Leonardi and R. Nanetti (1993), Making Democracy Work: Civic Traditions in Modern Italy, Princeton University Press, Princeton, NJ.

Rey, S. and B. Montouri (2010), "Regional studies US regional income convergence: A spatial econometric perspective", rsa.tandfonline.com, Vol. 33/2, pp. 143-156, http://dx.doi.org/10.1080/00343409950122945.

Rosenthal, S. and W. Strange (2004), "Evidence on the nature and sources of agglomeration economies", Handbook of Regional and Urban Economics, Vol. 4, pp. 2119-2171, http://dx.doi.org/10.1016/S0169-7218(04)07049-2.

Rupasingha, A., S. Goetz and D. Freshwater (2006), "The production of social capital in US counties”, Journal of Socio-Economics, Vol. 35/1, pp. 83-101, http://dx.doi.org/10.1016/j.socec.2005.11.001.

Rupasingha, A., S. Goetz and D. Freshwater (2005), "Social and institutional factors as determinants of economic growth: Evidence from the United States counties", Papers in Regional Science, Vol. 81/2, pp. 139-155, http://dx.doi.org/10.1111/j.14355597.2002.tb01227.x.

Rupasingha, A., S. Goetz and D. Freshwater (2000), "Social capital and economic growth: A county-level analysis", Journal of Agricultural and Applied Economics, Vol. 32/3, pp. 565-572, http://dx.doi.org/10.1017/s1074070800020654.

Simon, C. (1998), "Human Capital and Metropolitan Employment Growth", Journal of Urban Economics, Vol. 43/2, pp. 223-243, http://dx.doi.org/10.1006/juec.1997.2048.

Simon, C. and C. Nardinelli (2002), "Human capital and the rise of American cities, 1900-1990", Regional Science and Urban Economics, Vol. 32/1, pp. 59-96, http://dx.doi.org/10.1016/S0166-0462(00)00069-7.

Stephens, H. and J. Deskins (2018), "Economic distress and labor market participation", American Journal of Agricultural Economics, Vol. 100/5, pp. 1336-1356, http://dx.doi.org/10.1093/ajae/aay065. 
Tsvetkova, A., T. Conroy and J. Thill (2019), "Surviving in a high-tech manufacturing industry: the role of innovative environment and proximity to metropolitan industrial portfolio", International Entrepreneurship and Management Journal, pp. 1-27, http://dx.doi.org/10.1007/s11365-019-00591-8.

Tsvetkova, A., M. Partridge and M. Betz (2019), "Self-employment effects on regional growth: a bigger bang for a buck?", Small Business Economics, Vol. 52/1, pp. 27-45, http://dx.doi.org/10.1007/s11187-018-9988-5.

Tsvetkova, A., M. Partridge and M. Betz (2017), "Entrepreneurial and employment responses to economic conditions across the rural-urban continuum", Annals of the American Academy of Political and Social Science, http://dx.doi.org/10.1177/0002716217711884.

US Department of Agriculture Economic Research Service (2020), Population and Migration: Overview, https://www.ers.usda.gov/topics/rural-economy-population/population-migration/ (accessed on 31 March 2020).

Watson, P. and S. Deller (2017), "Economic diversity, unemployment and the Great Recession", Quarterly Review of Economics and Finance, Vol. 64, pp. 1-11, http://dx.doi.org/10.1016/j.gref.2016.12.003.

Weinstein, A., M. Partridge and A. Tsvetkova (2018), "Follow the money: Aggregate, sectoral and spatial effects of an energy boom on local earnings", Resources Policy, http://dx.doi.org/10.1016/..resourpol.2017.11.018. 